\title{
THE Alarm Bell IS SOUNDING AND THE \\ REGULATOR IS AT THE DOOR: EMERGENCY RESPONSE, REPORTING, AND INVESTIGATIONS IN THE AGE OF HEIGHTENED COMPLIANCE MONITORING AND ENFORCEMENT
}

\author{
Allison Sears, Marianne (ChUCK) Davies, \\ AND CONOR CHELL ${ }^{*}$
}

\begin{abstract}
In light of recent disasters in the oil and gas industry, there is increasing public pressure to develop more robust processes for responding to such disasters in Canada. In this article, the authors examine the emergency response procedures currently in place, and consider how oil and gas producers, carriers, and processors can improve these procedures. The article begins by outlining the emergency response planning and incident reporting obligations incumbent on the oil and gas industry, which is followed by an overview of the regulatory inspection powers that exist to investigate real and potential environmental, workplace, and safety incidents. Finally, the article considers what responding to an actual emergency would look like, and proposes best practices for the oil and gas industry.
\end{abstract}

TABLE OF CONTENTS

I. INTRODUCTION . . . . . . . . . . . . . . . . . . . . . . . . . . . . 367

II. EMERGENCY RESPONSE PLANNING AND

INCIDENT REPORTING OBLIGATIONS . . . . . . . . . . . . . . . . . . . . . . 368

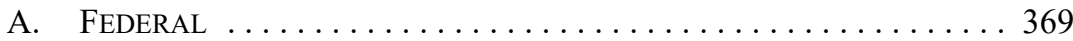

B. Alberta . . . . . . . . . . . . . . . . . . . . . . 385

III. InSPECTION AND INVESTIGATION POWERS AND PRACTICES . . . . . . . . . 395

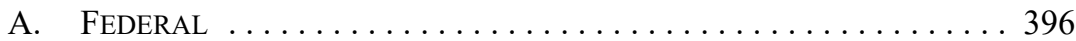

B. Alberta ......................... 410

IV. INCIDENT RESPONSE AND INVESTIGATION MANAGEMENT . . . . . . . 417

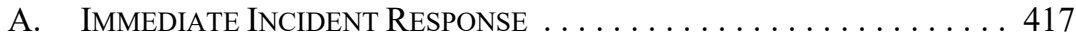

B. MANAGING REGULATORY INSPECTIONS AND

INVESTIGATIONS IN THE AFTERMATH OF AN INCIDENT . . . . . . . 430

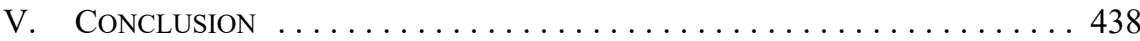

\section{INTRODUCTION}

We have entered an era of heightened regulatory compliance monitoring and enforcement by various government ministries, agencies, and administrative tribunals. As concerns over environmental protection and the adequacy of legislated emergency response requirements and oversight have become widespread, and "social licence" movements have gained traction, the public is demanding that regulators take increased action to enforce existing energy, environmental, and health and safety legislation, and that governments broaden

Allison Sears, Senior Counsel, Stikeman Elliott LLP. Marianne (Chuck) Davies, Senior Manager, Legal Counsel Regulatory, Nexen Energy ULC. Conor Chell, Legal Counsel, Upstream, Suncor Energy Inc. The authors would like to thank Meaghan Simister, an associate at Stikeman Elliott LLP, for her research assistance. The views expressed in this article are those of the authors alone and not their respective firms, organizations, or clients. This article is not intended to be an exhaustive review of all applicable energy, environmental, and health and safety legislation and should not be relied upon as such. 
enforcement powers as well as statutory liability for owners and operators of energy infrastructure. Recent industrial disasters such as the Deepwater Horizon oil spill, the LacMégantic derailment, and other large-scale pipeline spills, including recent spills in Alberta and Saskatchewan, have focused the public's attention on emergency spill response and workplace safety issues.

Remember BP's approved Regional Oil Spill Response Plan for the Gulf of Mexico, which, among other glaring errors, famously listed walruses, sea otters, sea lions, and seals (none of which are found in the Gulf) as sensitive species in the area? ${ }^{1}$ Media attention surrounding the inadequacies of this plan served to highlight the prevalence of boilerplate emergency response plans and a general lack of emergency preparedness. The deficiencies in such plans begged more rigorous regulatory oversight, including ensuring the actual ability of proponents to carry them out in the event of a serious incident.

Against this backdrop, we examine emergency response and reporting obligations as well as regulatory investigation powers relevant to the oil and gas industry, including the upstream, midstream, and downstream sectors. We focus in particular on Federal (onshore) and Alberta energy, environmental, and occupational health and safety legislation. This article proceeds in three parts. In Part II, we outline emergency response planning requirements under various pieces of legislation as well as corollary incident reporting obligations, including statutorily-mandated investigation reports. In Part III, we identify the statutory inspection and investigation powers of various regulators, including the National Energy Board (NEB or Board), the Transportation Safety Board (TSB), Environment and Climate Change Canada (ECCC), Fisheries and Oceans Canada (DFO), Transport Canada - Transportation of Dangerous Goods Directorate (TDG Directorate), the Alberta Energy Regulator (AER), Alberta Labour — Occupational Health and Safety (AOHS), and Alberta Transportation - Dangerous Goods and Rail Safety Branch (ATDG). Distinctions in the scope of powers of the various regulators and their differing practices and processes are discussed. In Part IV, we assume a major incident has occurred and provide practical insight into navigating the response and aftermath from a legal perspective. We address the role of internal and external legal counsel throughout the entire incident response horizon, including in any subsequent internal investigations and investigations conducted by regulators. Controversial issues, such as maintaining privilege over evidence gathered as part of the organization's internal investigation, presence of counsel in witness interviews, and when rights under the Canadian Charter of Rights and Freedoms ${ }^{2}$ may be triggered, are all explored.

\section{Emergency Response Planning ANd INCIDENT REPORTING OBLIGATIONS}

In the sections that follow, we have attempted to capture the main pieces of both Federal and Alberta legislation pursuant to which oil and gas producers, carriers, and processors have emergency response obligations and incident reporting obligations. In addition to these and

BP, Regional Oil Spill Response Plan (30 June 2009) at 249, online: <housedocs.house.gov/energy commerce/Docs 06152010/BP.Oil.Spill.Response.Plan.pdf>.

Part I of the Constitution Act, 1982, being Schedule B to the Canada Act 1982 (UK), 1982, c 11 [Charter]. 
other legislative requirements, it must be remembered that obligations will also be set out in the operator's various operating approvals. Among other reporting obligations, for example, most operating approvals require the immediate reporting of any contraventions of the specific terms and conditions under that particular approval. Accordingly, reference must be had to both the applicable legislation and the applicable operational permits and approvals when addressing emergency response planning and incident reporting.

\section{A. Federal \\ 1. NATIONAL ENERGY BOARD ACT \\ a. Emergency Response Planning Obligations}

Companies with interprovincial or international onshore pipelines and associated facilities governed as federal undertakings under the National Energy Board Act ${ }^{3}$ have emergency response planning obligations under the National Energy Board Onshore Pipeline Regulations $^{4}$ and the National Energy Board Processing Plant Regulations. ${ }^{5}$

Pursuant to section 32(1) of the OPR, companies must "develop, implement and maintain an emergency management program that anticipates, prevents, manages and mitigates conditions during an emergency that could adversely affect property, the environment or the safety of workers or the public." ${ }^{\prime}$ Additionally, companies must develop an emergency procedures manual (EPM) ${ }^{7}$ review it regularly, make updates to it as required, and submit it to the Board. ${ }^{8}$ Similar requirements are set out in section 35 of the $P P R$, which applies to hydrocarbon processing plants falling within the definition of "pipeline" under the NEB Act (but does not include well site or field facilities). ${ }^{9}$ As defined in the $P P R$, processing plant means "a plant used for processing, extraction or conversion of fluids and all structures located within the boundaries of the plant, including compressors and other structures integral to the transportation of fluids." 10

Detailed guidance on the minimum content to be included in a company's emergency management program, and in its EPM, can be found in Annex A to the NEB's Guidance Notes for the National Energy Board Onshore Pipeline Regulations (Guidance Notes). ${ }^{11}$ In particular, it outlines the hazard assessment process to be used in delineating emergency planning zones, sets out minimum content for EPMs, and provides guidance on continuing

RSC 1985, c N-7 [NEB Act].

$\mathrm{SOR} / 99-294$, ss 32-35 [OPR].

SOR/2003-39, ss 35-39 [PPR].

OPR, supra note 4, s 32(1).

The EPM is also known as an "Emergency Response Plan" in CSA Group, CAN/CSA - Z246.2-14, Emergency Preparedness and Response for Petroleum and Natural Gas Industry Systems (Toronto: CSA Group, 2014) at 21.

OPR, supra note 4, ss 32(1.1)-32(2).

PPR, supra note $5, \mathrm{~s} 2$.

Ibid, s 1 .

Canada, National Energy Board, "Guidance Notes for the National Energy Board Onshore Pipeline Regulations" (4 September 2013), online: < https:/www.neb-one.gc.ca/bts/ctrg/gnnb/nshrppln/gdncntn shrpplnrgltn-eng.html $>$ [NEB, "Guidance Notes"]. See also Canada, National Energy Board, "Emergency Procedures Manuals: Letter to All Oil and Gas Companies under the Jurisdiction of the National Energy Board and Interested Persons" (26 March 2015), online: <https://www.neb.gc.ca/bts/ ctrg/gnnb/nshrppln/2015-03-26nbl-eng.html> [NEB, “EPM Letter”]. 
engagement with other agencies that would have a role in emergency response, including first responders, city planners, municipalities, and Indigenous groups, which must take place during the development and annual updating of the EPM..$^{12}$ Notably, the company must "develop a continuing education program for the police, fire departments, medical facilities, other appropriate organizations and agencies and the public residing adjacent to" the pipeline. ${ }^{13}$ The continuing education program is intended to inform these groups about "the location of the pipeline, potential emergency situations involving the pipeline and the safety procedures to be followed in the case of an emergency." 14 Additionally, companies are required to conduct audits of their emergency management programs at least every three years ${ }^{15}$ and are expected to conduct emergency response exercises with sufficient frequency, which the NEB indicates should include one simulated (that is, tabletop) exercise annually, and a full-scale exercise involving all agencies at least every three years. ${ }^{16}$

Companies must file both one hard copy and one electronic copy of their EPMs with the NEB. ${ }^{17}$ In addition, when filing EPM updates as required under sections 32(2) of the OPR and 35(c) of the $P P R$, companies must also file a new complete EPM in both electronic and hard copy, incorporating all updates. Companies must, at a minimum, "file annual EPM updates by 1 April of each year or alternatively, file a letter indicating that there have been no changes to their EPM."18

Consistent with the trend toward transparency and accountability for emergency preparedness, in accordance with NEB Order MO-006-2016, "all companies that hold an authorization to construct and operate an oil or a gas pipeline, or a gas processing plant, regulated by the Board" must publish the EPMs applicable to their NEB-regulated facilities on their websites for public viewing (subject to protections for personal information, matters of national security, and third party confidentiality) by 30 September 2016 , unless otherwise directed by the Board. ${ }^{19}$ Companies must have also provided the Board with written confirmation, by 17 October 2016, that the company's EPMs have been published in accordance with the Order. ${ }^{20}$ This Order came in response to the NEB's public Emergency Management Transparency Consultation and was noted to be the first step in making more emergency management information publicly available. ${ }^{21}$ In early 2017 , the NEB issued Order MO-002-2017 compelling companies to publish on their websites additional information related to the company's emergency response program, beyond the information

OPR, supra note 4, s 33; PPR, supra note 5, s 36.

OPR, ibid, s 35; PPR, ibid, s 38.

OPR, ibid.

OPR, ibid, s 55(1)(a).

Ibid; NEB, "Guidance Notes," supra note 11, Annex A.

NEB, "EPM Letter," supra note 11.

Ibid.

Canada, National Energy Board, "Order MO-006-2016 Compelling Publication of Emergency Procedures Manuals” (5 April 2016), online: <https://www.neb-one.gc.ca/sftnvrnmnt/mrgnc/rspns/nbl 2016-04-05-eng.html>.

20 Ibid.

The Emergency Management Transparency Consultation was held in April through June of 2015. 
captured in the EPM. ${ }^{22}$ Appendix A to the Order outlines the extensive emergency management program information that companies must publish by 31 July 2017.

\section{b. Incident Reporting Obligations}

An "incident" is defined under the $O P R$ as meaning an occurrence that results in any of the following:

(a) the death of or serious injury ${ }^{23}$ to a person;

(b) a significant adverse effect on the environment;

(c) an unintended fire or explosion;

(d) an unintended or uncontained release of [low vapour pressure (LVP)] hydrocarbons in excess of $1.5 \mathrm{~m}^{3}$;

(e) an unintended or uncontrolled release of gas or [high vapour pressure (HVP)] hydrocarbons;

(f) the operation of a pipeline beyond its design limits as determined under CSA Z662 ${ }^{24}$ or CSA Z276 or any operating limits imposed by the Board. ${ }^{25}$

Pursuant to section 52(1) of the $O P R$, a company must (1) "immediately notify the [NEB] of any incident relating to the construction, operation or abandonment of its pipeline"; and (2) "submit a preliminary and detailed incident report to the [NEB] as soon as is practicable." $" 26$

Under the $P P R$, "incident" is defined more generally as meaning any "occurrence that results or could result in a significant adverse effect on property, the environment or the safety of persons." 27 Section 46 of the PPR mirrors section 52 of the OPR with respect to incident reporting. Additionally, section 47 of the PPR mandates the reporting by a company of any "hazard that renders or may render its processing plant unsafe to operate" 28 and, as soon as practicable, submission of a report assessing the hazard identified "including a proposed contingency plan and a description of the cause, duration and potential impacts of the hazard, of repairs to be made and of measures to prevent future failures." ${ }^{29}$

Canada, National Energy Board, "Order MO-002-2017 Compelling Publication of Emergency Management Program Information on Company Websites" (30 January 2017), online: <https://www. neb-one.gc.ca/sftnvrnmnt/mrgnc/rspns/nbl2017-01-30-eng.pdf $>$. The order applies to all NEB-regulated pipelines and processing plants with the exception of those that are deactivated, decommissioned or abandoned, as well as certain small diameter pipelines that are not located in proximity to water sources. A "serious injury" is defined non-exhaustively under section 1 of the $O P R$ to include an injury that results in

(a) the fracture of a major bone;

(b) the amputation of a body part;

(c) the loss of sight in one or both eyes;

(d) internal hemorrhage;

(e) third degree burns;

(f) unconsciousness; or

(g) the loss of a body part or function of a body part.

Notably, both federally regulated pipelines and pipelines regulated by the AER must be designed, constructed, and operated in accordance with CSA Group, CAN/CSA - Z662-15, Oil and Gas Pipeline Systems (Toronto: CSA Group, 2015) [CSA - Z662-15]. See OPR, supra note 4, s 4; Pipeline Rules, Alta Reg 91/2005, s 9).

OPR, ibid, $\mathrm{s} 1$.

Ibid, s 52(1).

$P P R$, supra note $5, \mathrm{~s} 1$. Notably, the definition under the PPR is less specific and is focused on the impacts of the event, whereas the definition under the $O P R$ is more specific and is focused on the simple occurrence of the event.

PPR, ibid, s 47(a).

Ibid, s 47(b). 
As we outline in greater detail in Part III, below, the TSB also plays a role in the investigation of incidents involving federally regulated pipelines pursuant to the Canadian Transportation Accident Investigation and Safety Board Act. ${ }^{30}$ In particular, the TSB is responsible for investigating transportation occurrences, which include "pipeline occurrences," defined broadly as meaning "any accident or incident associated with the operation of a pipeline," and "any situation or condition that the Board has reasonable grounds to believe could, if left unattended, induce an accident or incident. ${ }^{\text {"31 }}$ Reporting requirements with respect to pipeline occurrences are addressed in Part 1 of the Transportation Safety Board Regulations. ${ }^{32}$ Section 4 sets out the particular pipeline occurrences that the operator of a federally regulated pipeline must report ${ }^{33}$ as well as all information required to be reported as soon as possible. ${ }^{34}$ Notably, while the particular "pipeline occurrences" to be reported to the TSB are similar to the "incidents" to be reported to the NEB, they are not identical, the former being broader. ${ }^{35}$

The NEB and TSB have established a single-window online event reporting system for reporting pipeline incidents and occurrences. ${ }^{36}$ The TSB must, however, be alerted immediately by telephone in the event of a "serious pipeline occurrence", which it defines as an occurrence that results in (1) loss of human life; (2) a serious injury as defined in either the OPR or the TSB Regulations; (3) a fire or explosion that causes a pipeline or facility to be inoperative; (4) a low vapour pressure hydrocarbon release in excess of 1.5 cubic metres that leaves company property or the right-of-way; (5) a rupture (that is, instantaneous release that immediately impairs the operation of a pipeline such that pressure cannot be maintained); or (6) a toxic plume (as defined in CSA Z662). ${ }^{37}$

\section{CANADA OIL AND GAS OPERATIONS ACT}

Though the unique regulatory framework governing offshore exploration, production, and transportation is beyond the scope of this article, and while we are mostly interested in the legislation governing the NEB's oversight of interprovincial and international pipelines, we will briefly touch on the emergency response planning and reporting requirements set out in

SC 1989, c 3 [TSB Act].

Ibid, $\mathrm{s} 2$.

SOR/2014-37 [TSB Regulations].

Ibid, $\mathrm{s} 4(1)$.

Ibid, ss 4(2)-(3).

See ibid, ss 4(1)(a)-(j) (pipeline occurrences that are reportable under the TSB Regulations include, among others, circumstances where "the pipeline restricts the safe operation of any mode of transportation"; "an unauthorized third party activity within the safety zone that poses a threat to the safe operation of the pipeline"; "a geotechnical, hydraulic or environmental activity that poses a threat to the safe operation of the pipeline"; or "the operation of a portion of the pipeline is interrupted as a result of a situation or condition that poses a threat to any person or property or the environment").

36 Canada, National Energy Board, "Event Reporting," online: < https://apps.neb-one.gc.ca/ERS/Home/ Index/s.

37 See online: Transportation Safety Board of Canada $<$ www.tsb.gc.ca/eng/incidents-occurrence/pipeline/ index.asp>. 
the Canada Oil and Gas Operations Act. ${ }^{38}$ The COGOA governs the exploration and production of oil and gas on lands subject to federal jurisdiction. ${ }^{39}$

\section{a. Emergency Response Planning Obligations}

Among other requirements, before the NEB issues any authorization under the COGOA, it must "consider the safety of the work or activity by reviewing, in consultation with the Chief Safety Officer, the system as a whole and its components, including its installations, equipment, operating procedures and personnel." ${ }^{40}$ Pursuant to the Canada Oil and Gas Drilling and Production Regulations, ${ }^{41}$ applicants for authorizations must have in place management systems that include "the processes for identifying hazards and for evaluating and managing the associated risks," as well as "the processes for the internal reporting and analysis of hazards, minor injuries, incidents and near-misses and for taking corrective actions to prevent their recurrence." ${ }^{42}$ Applications for authorizations must also be accompanied by, among other things, a safety plan that meets the detailed requirements set out in section 8 of the COGDPR, ${ }^{43}$ and an environmental protection plan that meets the detailed requirements set out in section $9 .{ }^{44}$ Additionally, such applications must include "contingency plans, including emergency response procedures, to mitigate the effects of any reasonably foreseeable event that might compromise safety or environmental protection." These emergency response procedures must "provide for coordination measures with any relevant municipal, provincial, territorial or federal emergency response plan," and "in an offshore area where oil is reasonably expected to be encountered, identify the scope and frequency of the field practice exercise of oil spill countermeasures." ${ }^{\prime 6}$ Further requirements relating to safety and environmental protection are set out in section 19 of the COGDPR.

\section{b. Incident Reporting Obligations}

Where a spill occurs on lands to which the COGOA applies, it must be immediately reported to the Chief Conservation Officer and "all reasonable measures consistent with safety and the protection of the environment" must be taken to remedy the condition and

RSC 1985, c O-7 [COGOA].

In particular, section 3 of the COGOA, ibid, provides that it applies to

(a) that part of the onshore that is under the administration of a federal minister,

(b) Nunavut,

(c) Sable Island,

(d)that part - of the internal waters of Canada or the territorial sea of Canada - that is not situated

(i) in a province other than the Northwest Territories, or

(ii) in that part of the onshore that is not under the administration of a federal minister, and

(e) the continental shelf of Canada and the waters superjacent to the seabed of that

continental shelf,

other than of oil and gas in the adjoining area, as defined in section 2 of the Yukon Act. COGOA

SOR/2009-315 [COGDPR].

Ibid, ss 5(2)(c), (f).

Ibid, s 6(c).

Ibid, s 6(d).

Ibid, s 6(j).

Ibid, ss 6(j)(i)-(ii). 
"mitigate any danger to life, health, property or the environment." ${ }^{47}$ The Chief Conservation Officer may take over management of the site of the spill if satisfied that the necessary immediate action is not being taken by the operator. ${ }^{48}$ Additionally, pursuant to section 75 of the COGDPR, operators must notify the NEB "of any incident or near-miss as soon as the circumstances permit. ${ }^{, 49}$ Except in an emergency situation, the operator must also give 24 hours' prior notice to the NEB of any press release or press conference to be held in respect of the incident ${ }^{50}$ Incident is defined under the COGDPR as meaning:

(a) any event that causes

(i) a lost or restricted workday injury,

(ii) death,

(iii) fire or explosion,

(iv) a loss of containment of any fluid from a well,

(v) an imminent threat to the safety of a person, installation or support craft, or

(vi) pollution;

(b) any event that results in a missing person; or

(c) any event that causes

(i) the impairment of any structure, facility, equipment or system critical to the safety of persons, an installation or support craft, or

(ii) the impairment of any structure, facility, equipment or system critical to environmental protection. $^{51}$

Thereafter, the operator must ensure that the incident or near-miss is investigated, its root cause and causal factors identified, and corrective action taken. ${ }^{52} \mathrm{~A}$ copy of the investigation report must be submitted to the NEB no later than 21 days after the incident occurred for the following events: "(i) a lost or restricted workday injury, (ii) death, (iii) fire or explosion, (iv) a loss of containment of any fluid from a well, (v) an imminent threat to the safety of a person, installation or support craft, or (vi) a significant pollution event."${ }^{, 53}$

\section{CANADA LABOUR CODE - PART II}

Part II of the Canada Labour Code ${ }^{54}$ governs occupational health and safety at the federal level and its purpose is "to prevent accidents and injury to health arising out of, linked with or occurring in the course of employment." ${ }^{55}$ It applies to federal public service and to federally regulated industries, including to the exploration and development of petroleum on lands subject to federal jurisdiction, pipelines, railways, highway transport, and shipping and

COGOA, supra note 38, s 25(3). Section 6 of the Canada Oil and Gas Operations Regulations, SOR/83149 , provides that the Chief Conservation Officer is to be informed "forthwith of the circumstances and relevant details of the spill by the most rapid and practical means."

COGOA, ibid, ss 25(4)-(5).

COGDPR, supra note $41, \mathrm{~s} 75(1)(\mathrm{a})$.

Ibid, s 75(1)(b).

Ibid, s 1(1). A "near-miss" is, in turn, defined as "an event that would likely cause an event set out in paragraph (a) of the definition of incident, but does not due to particular circumstances" (ibid).

Ibid, s 75(2)(a).

Ibid, s 75(2)(b).

RSC 1985, c L-2 [CL Code].

Ibid, s 122.1 . 
shipping services. ${ }^{56}$ Additionally, the provisions of the Canada Occupational Health and Safety Regulations ${ }^{57}$ apply to employees employed on or in connection with the transportation of oil or gas through an interprovincial pipeline, ${ }^{58}$ whereas the Oil and Gas Occupational Safety and Health Regulations ${ }^{59}$ apply to employees employed on or in connection with exploration or drilling for, or the production, conservation, processing or transportation (other than transportation through an interprovincial pipeline) of, oil or gas on "Canada lands," as defined in the Canada Oil and Gas Act. ${ }^{60}$

\section{a. Emergency Response Planning Obligations}

Where NEB regulated pipelines are concerned, Part XVII of the COHS Regulations governs the safe occupancy of the work place and addresses emergency response planning obligations. $^{61}$ An emergency evacuation plan must be prepared in accordance with the requirements, and include the minimum contents, set out in section 17.4 of the COHS Regulations. Additionally, in accordance with section 17.5(1), every employer must prepare emergency procedures:

(a) to be implemented if any person commits or threatens to commit an act that is likely to be hazardous to the health and safety of the employer or any of his or her employees;

(b) if there is a possibility of an accumulation, spill or leak of a hazardous substance in a work place controlled by the employer, to be implemented in the event of such an accumulation, spill or leak;

(c) if more than 50 employees are working in a building at any time, to be implemented when evacuation is not an appropriate means of ensuring the health and safety of employees;

(d) to be implemented in the event of a failure of the lighting system; and

(e) to be implemented in the event of a fire. ${ }^{62}$

The emergency procedures must include:

(a) an emergency evacuation plan, where applicable, or a plan for evacuating employees who require special assistance to be implemented in the event of a fire;

(b) a full description of the procedures to be followed;

(c) the location of the emergency equipment provided by the employer; and

(d) a plan of the building. ${ }^{63}$

Canada, Human Resources and Skills Development, "Information on Occupational Health and Safety - Pamphlet 1 Summary of Part II of the Canada Labour Code" (Quebec: HRSD, 2012), online: <publications.gc.ca/collections/collection_2012/rhdcc-hrsdc/HS23-1-1-2011-eng. pdf > . SOR/86-304 [COHS Regulations].

Ibid, s 1.4(d).

SOR/87-612 [OGOSH Regulations].

Ibid, s 1.3(1). Note that the Canada Oil and Gas Act, RS 1985, c O-6 was repealed by the Canada Petroleum Resources Act, RSC 1985, c 36 (2nd Supp) and "Canada lands" is now captured by the term "frontier lands" as defined in section 2 of the Canada Petroleum Resources Act and as addressed in section 3 of the COGOA, supra note 38.

COHS Regulations, supra note 57.

Ibid, s 17.5(1).

Ibid, s 17.5(2). 
Further, every employee must be instructed and trained in "the procedures to be followed in the event of an emergency," and "the location, use and operation of fire protection equipment and emergency equipment provided by the employer." 64

In respect of oil and gas operations related to the exploration or drilling for or the production, conservation, processing, or transportation (other than transportation through an interprovincial pipeline) of oil or gas on frontier lands, Part XVIII of the OGOSH Regulations governs the safe occupancy of the work place and addresses emergency response planning obligations in substantially similar terms as those described above existing under the COHS Regulations. Emergency procedures are addressed in sections 18.9 and 18.10 of the OGOSH Regulations, and emergency evacuation plans are addressed in sections 18.11 and 18.12 .

\section{b. Incident Reporting Obligations}

In accordance with section 125(1)(c) of the CL Code, employers must "investigate, record and report in the manner and to the authorities as prescribed all accidents, occupational diseases and other hazardous occurrences known to the employer." ${ }^{65}$ Hazardous occurrence investigation, recording, and reporting requirements are specifically addressed in Part XV of the COHS Regulations. Pursuant to section 15.4(1),

[w] here an employer becomes aware of an accident, occupational disease, or other hazardous occurrence affecting any of [its] employees in the course of employment, the employer shall, without delay,

(a) appoint a qualified person to carry out an investigation of the hazardous occurrence;

(b) notify the work place committee or the health and safety representative of the hazardous occurrence and of the name of the person appointed to investigate it; and

(c) take necessary measures to prevent a recurrence of the hazardous occurrence. ${ }^{66}$

\section{Additionally, the employer must}

report to the Minister ... the date, time, location and nature of any accident, occupational disease or other hazardous occurrence referred to in section 15.4 that had one of the following results, as soon as feasible but not later than 24 hours after becoming aware of that result:

(a) the death of an employee;

(b) a disabling injury ${ }^{67}$ to two or more employees;

Ibid, ss 17.6(1)(a)-(b).

CL Code, supra note 54, s 125(1)(c).

COHS Regulations, supra note 57, s 15.4(1).

A "disabling injury" is defined under section 15.1 of the COHS Regulations, ibid as meaning an employment injury or an occupational disease that

(a) prevents an employee from reporting for work or from effectively performing all the duties connected with the employee's regular work on any day subsequent to the day on which the injury or disease occurred, whether or not that subsequent day is a working day for that employee,

(b) results in the loss by an employee of a body member or part thereof or in the complete loss of the usefulness of a body member or part thereof, or

(c) results in the permanent impairment of a body function of an employee. 
(c) the loss by an employee of a body member or a part thereof or the complete loss of the usefulness of a body member or a part thereof;

(d) the permanent impairment of a body function of an employee;

(e) an explosion;

(f) damage to a boiler or pressure vessel that results in fire or the rupture of the boiler or pressure vessel; or

(g) any damage to an elevating device that renders it unserviceable, or a free fall of an elevating device. $^{68}$

Where the internal investigation contemplated under section 15.4(1) discloses that the hazardous occurrence resulted in any of the following, the employer must make a report to the Minister in writing in the form set out in Schedule I within 14 days of the hazardous occurrence: ${ }^{69}$

(a) a disabling injury to an employee;

(b) an electric shock, toxic atmosphere or oxygen deficient atmosphere that caused an employee to lose consciousness;

(c) the implementation of rescue, revival or other similar emergency procedures; or

(d) a fire or an explosion. ${ }^{70}$

Substantially similar hazardous occurrence investigation, recording, and reporting requirements are set out in Part XVI of the OGOSH Regulations. Reporting is also required, however, where the hazardous occurrence resulted in a missing person, an accidental accumulation, spill or leak of a hazardous substance, or the loss of or damage to support craft. $^{71}$

Finally, it bears noting that under section 127 of the CL Code,

if an employee is killed or seriously injured in a work place, no person shall, unless authorized to do so by the Minister, remove or in any way interfere with or disturb any wreckage, article or thing related to the incident except to the extent necessary to

(a) save a life, prevent injury or relieve human suffering in the vicinity;

(b) maintain an essential public service; or (c) prevent unnecessary damage to or loss of property. ${ }^{72}$

We note that this definition captures a broader range of reportable injuries than under the Alberta legislation, which captures only those injuries requiring a two-day hospital stay or more (Occupational Health and Safety Act, RSA 2000, c O-2, s 18(2)(b) [OHSA]). In practice, there are many injuries that require less than a two-day hospital stay, but can result in lengthy periods of time off work that are not reportable under the Alberta legislation.

68 COHS Regulations, ibid, s 15.5. We note that the timing for providing such reports, which focuses on the time that the employer actually becomes aware of a particular result, appears to be clearer than under Alberta's legislation. For example, under the Alberta legislation, reporting is required when a two-day hospital stay is required (OHSA, ibid), but it is not clear whether that event must be reported once the stay definitively reaches the 48 hour period or whether it is triggered when the employer becomes aware that the stay may or will be two days or more. Based on the authors' experience, AOHS appears to take the latter view, making early reporting the most prudent approach.

COHS Regulations, ibid, s 15.8(2)(b).

Ibid, s 15.8(1).

OGOSH Regulations, supra note 59, s 16.4(1).

CL Code, supra note 54, s 127(1). The Minister's authorization is not, however, needed where the accident is being investigated under the TSB Act, supra note 30 (CL Code, ibid, s 127(2)). 


\section{CANADIAN ENVIRONMENTAL PROTECTION ACT, 1999}

\section{a. Emergency Response Planning Obligations}

Though a company's oil and gas operations may not otherwise be federally regulated, if a company has charge, management, or control of a substance in a quantity, with the characteristics, and stored in the conditions, all set out in Schedule 1 to the Environmental Emergency Regulations, ${ }^{73}$ the company must prepare an environmental emergency plan (EEP). ${ }^{74}$

The E2 Regulations are passed under Part 8 of the Canadian Environmental Protection Act, $1999,{ }^{75}$ which aims to prevent, prepare for, respond to, and recover from environmental emergencies. An environmental emergency is defined as "an uncontrolled, unplanned or accidental release, or release in contravention of regulations or interim orders," of a substance listed in Schedule 1 to the E2 Regulations into the environment (or the reasonable likelihood of such a release). ${ }^{76}$ The substances in Schedule 1 to the E2 Regulations have been listed because

if they enter the environment as a result of an environmental emergency,

(i) [they would] have or may have an immediate or long-term harmful effect on the environment or its biological diversity,

(ii) [they would] constitute or may constitute a danger to the environment on which human life depends, or

(iii) [they would] constitute or may constitute a danger in Canada to human life or health. ${ }^{77}$

The particular quantities, characteristics, and storage conditions that trigger the need for preparation of an EEP are set out in section 4(1) of the E2 Regulations. The factors that must be considered in preparing the EEP are:

(a) the properties and characteristics of the substance and the maximum expected quantity of the substance at the place at any time during a calendar year;

(b) the commercial, manufacturing, processing or other activity in relation to which the plan is to be prepared;

(c) the characteristics of the place where the substance is located and of the surrounding area that may increase the risk of harm to the environment or of danger to human life or health; and

(d) the potential consequences from an environmental emergency on the environment and on human life or health. $^{78}$

A list of the minimum required contents of the EEP are set out in section 4(3) of the E2 Regulations. Notably, in accordance with section 7, if a company has already prepared a plan

SOR/2003-307 [E2 Regulations].

Ibid, ss 3(1), 4.

SC 1999, c 33 [CEPA].

Ibid, s 193.

Ibid, s 200(1)(a).

E2 Regulations, supra note 73, s 4(2). 
for another government, which would include a provincial government or regulator such as the AER, or under another federal statute that meets the requirements set out in section 4(3) (or can be amended to meet all such requirements) the company can rely on that plan (or amended plan) for the purpose of meeting the EEP requirements. ${ }^{79}$

Though the EEP need not be filed with ECCC unless specifically requested, the company is required to meet certain notice requirements. In particular, the company must file a notice of identification of substance providing the information set out in Schedule 2 within 90 days of the E2 Regulations coming into force, or 90 days after a substance reaches or exceeds its prescribed quantity. ${ }^{80}$ Thereafter, within six months of the E2 Regulations coming into force, or six months after a substance reaches or exceeds the prescribed quantity, the company must file a notice of preparation of the EEP, confirming that it has been prepared and providing the information required in Schedule $4 .^{81}$ Finally, the company must file a notice of implementation meeting the information requirements set out in Schedule 5 within a year of the E2 Regulations coming into force, or a year after a substance reaches or exceeds the prescribed quantity. ${ }^{82}$ The EEP must be updated and tested at least once each calendar year to ensure that it continues to meet the requirements of the E2 Regulations. ${ }^{83}$

At the time of writing, the E2 Regulations were in a state of flux and expected to be repealed and replaced with the proposed Environmental Emergency Regulations, $2016 .{ }^{84}$ The proposed changes include:

- the addition of 49 new substances to Schedule 1 [(16 of which are petroleum substances $)]$ and amendment of the thresholds for 3 existing substances;

- a clarification of the requirements for exercising an [EEP];

- a consolidation of substances into a single list;

- the inclusion of uncontained substances;

- a definition of a container system;

- clarifications for the requirements regarding public notifications before, during and after an environmental emergency; and

- modifications to reporting requirements including periodic reporting to ensure an up-to-date database is available for departmental officials and first responders. ${ }^{85}$

The key features of the proposed amendments include provisions ensuring that the public is "notified of the possibility and potential consequences of an environmental emergency, as well as of the measures that would be taken ... to protect human life and health and the

${ }_{80}^{79} \quad$ Ibid, $\mathrm{s} 7(1)$.

Ibid, ss 3(1), 3(3). See also Environment and Climate Change Canada, "Environmental Emergency Regulations (E2) - File a Notice" (31 May 2016), online: <www.ec.gc.ca/ee-ue/default.asp?lang=En $\& \mathrm{n}=38 \mathrm{C} 539 \mathrm{FE}-1>$.

E2 Regulations, ibid, ss 4(1), 4(4).

Ibid, s 5.

Ibid, s 6(1).

Proposed Regulations (Environmental Emergency Regulations, 2016), (2016) C Gaz 1, 3000 (Canadian Environmental Protection Act), online: <www.gazette.gc.ca/rp-pr/p1/2016/2016-10-08/html/reg2eng.php $>$ [Environmental Emergency Regulations, 2016] .

85 Environment and Climate Change Canada, "Invitation to Submit Comments to the Proposed Environmental Emergency Regulations, 2016 under the Canadian Environmental Protection Act, 1999" (25 October 2016), online: $<$ www.ec.gc.ca/ee-ue/default.asp?lang=En\&n=B2B4A2B2-1>. 
environment in the event of an environmental emergency." ${ }^{\text {" }}$ "There would also be strengthened requirements "that the public be provided with information and guidance on actions to be taken before, during, and after an emergency." ${ }^{87}$ EEP requirements would also be bolstered to ensure that there are adequate measures in place to address all emergency situations that may arise. ${ }^{8}$ We note that the underlying goals of the public notification provisions appear to be similar to legislation in place in other jurisdictions, including the United States. ${ }^{89}$

\section{b. Incident Reporting Obligations}

In accordance with section 201 of the CEPA, any person who owns or has the charge, management, or control of a substance listed in Schedule 1 to the E2 Regulations immediately before the environmental emergency, or who causes or contributes to the environmental emergency, must report the environmental emergency. ${ }^{90}$ The report must include the information set out in section 9 of the E2 Regulations and be provided to the "Regional Director of the Environmental Enforcement Division of the Enforcement Branch of the Department of the Environment" in the region where the environmental emergency occurs. ${ }^{91}$ Notably, an environmental emergency occurs when there is an uncontrolled, unplanned, or accidental release, or release in contravention of the regulations of a substance listed in Schedule 1 to the E2 Regulations into the environment, ${ }^{92}$ however, there is no reporting threshold volume established under the CEPA or the E2 Regulations. ${ }^{93}$

In addition to the foregoing environmental emergency reporting obligations in relation to substances under the E2 Regulations, there are release reporting obligations under the CEPA

Environmental Emergency Regulations, 2016, supra note 84 at 3005 [emphasis added].

Ibid.

Ibid.

For example, there are similar community notification requirements under the Emergency Planning and Community Right-to-Know Act, 42 USC ch 116 (2011), online: <https://www.gpo.gov/fdsys/pkg/US CODE-2011-title42/html/USCODE-2011-title42-chap116.htm > [EPCRA]. The EPCRA was passed in 1986 in the United States to address environmental and safety hazards posed by the storage and handling of toxic chemicals. The EPCRA requires that federal, state, and local governments, tribes, and industry report on hazardous and toxic chemicals. The EPCRA also requires the preparation of chemical emergency response plans, emergency notification, and community "right-to-know" measures. The community "right-to-know" requirements mandate that facilities handling or storing hazardous chemicals submit information to state and local officials and fire departments.

Supra note 75, ss 201(1)-(2).

E2 Regulations, supra note 73 , s 9.

CEPA, supra note 75 , s 193.

This issue was raised in consultations in respect of the proposed Environmental Emergency Regulations, 2016. In its "Regulatory Impact Analysis Statement," included with the proposed regulations, ECCC noted that numerous comments were received recommending the inclusion of release thresholds and of harmonizing the requirements with existing reporting requirements (Environmental Emergency Regulations, 2016, supra note 84 at 3016). ECCC indicated that it undertook a review of provincial regulations as well as the federal Transportation of Dangerous Goods Regulations, SOR/2001-286 [TDG Regulations] and found that some provincial governments have thresholds while others do not. ECCC also noted that the TDG Regulations thresholds are based primarily on public safety, whereas the current and proposed E2 Regulations primarily consider the environment and human health and life. Given these different policy intents, ECCC found that the proposed regulations should not be aligned with the TDG Regulations for purposes of establishing reporting thresholds and the E2 Regulations should continue to require reporting of all releases constituting environmental emergencies (Environmental Emergency Regulations, 2016, ibid). Where the oil and gas industry is concerned, this is a frustrating and inefficient conclusion given that there are already release reporting obligations with thresholds under provincial energy and environmental statutes. We expect that it will lead to confusion and duplication, and hope that it may be revisited, perhaps through an equivalency agreement between Canada and each of the impacted provinces under section 10 of the CEPA, supra note 75. 
in respect of (i) releases of toxic substances included on the List of Toxic Substances set out in Schedule 1 to the $C E P A ;{ }^{94}$ (ii) releases of substances into the air (in contravention of a regulation made under section 167 ) that may cause air pollution in another country; ${ }^{95}$ (iii) releases of substances into water (in contravention of a regulation made under section 177) that might cause water pollution in another country; ${ }^{96}$ and (iv) releases of substances by departments, boards and agencies of the Government of Canada, Crown corporations, a federal work or undertaking, or an activity on federal land or Aboriginal land, where such substances are captured under regulations. ${ }^{97} \mathrm{We}$ distinguish these substance release reporting obligations relating to inadvertent releases from the annual pollutant reporting to the National Pollutant Release Inventory (NPRI) that is required of certain facilities in accordance with section 46 of the CEPA.

Apart from NPRI reporting, all releases, including environmental emergencies, must be reported as soon as possible to the phone number provided in the Schedule to the Release and Environmental Emergency Notification Regulations ${ }^{98}$ for the province in which the release occurred. For Alberta, the number provided is operated by Alberta Environment and Parks in coordination with the AER and is the same number to be called for release reporting under the statutes administered by the AER.

\section{TRANSPORTATION OF DANGEROUS GOODS ACT, 1992}

At the outset, it should be noted that the Transportation of Dangerous Goods Act, $1992^{99}$ does not apply in relation to commodities transported by a pipeline governed by the NEBAct, the COGOA or the law of a province. Oil and gas producers are, however, increasingly reliant on transportation by truck or rail, making the TDGA one of the key pieces of legislation of interest in respect of spills. The TDGA is administered by TDG Directorate, which operates the Canadian Transport Emergency Centre (CANUTEC). While the TDGA covers the transportation of dangerous goods by road, rail, water, and air, we focus here only on road and rail.

Under the TDGA, "dangerous goods" is defined as "a product, substance or organism included by its nature or by the regulations in any of the classes listed in the schedule [to the TDGA]," ${ }^{100}$ which sets out nine classes of dangerous goods: (i) explosives (Class 1); (ii) gases that are compressed, deeply refrigerated, liquefied, or dissolved under pressure (Class 2); (iii) flammable and combustible liquids (Class 3); (iv) flammable solids, substances liable to spontaneous combustion, and substances that on contact with water emit flammable gases (Class 4); (v) oxidizing substances and organic peroxides (Class 5); (vi) poisonous (toxic) and infectious substances (Class 6); (vii) nuclear substances that are radioactive (Class 7);

$94 \quad$ CEPA, ibid, s 95(1).

95 Ibid, ss $167,169(1)$. We note that as of the time of writing, there were no regulations yet passed under section 167 .

96 Ibid, ss $177,179(1)$. We note that as of the time of writing, there were no regulations yet passed under section 177 .

97 Ibid, ss 207(1), 212(1). For associated regulations, see Storage Tank Systems for Petroleum Products and Allied Petroleum Products Regulations, SOR/2008-197 (but note that these regulations do not apply to storage tank systems regulated under the NEB Act or the COGOA).

SOR/2011-90.

SC 1992, c 34 [TDGA].

Ibid, s 2 . 
(viii) corrosives (Class 8); and (ix) "[m]iscellaneous products, substances, or organisms considered by the Governor in Council to be dangerous to life, health, property or the environment when handled, offered for transport or transported and prescribed to be included in this class" (Class 9). ${ }^{101}$

\section{a. Emergency Response Planning Obligations}

As per section 7(1) of the TDGA:

No person shall import, offer for transport, handle or transport dangerous goods in a quantity or concentration that is specified by regulation — or that is within a range of quantities or concentrations that is specified by regulation - unless the person has an [approved] emergency response assistance plan [(ERAP)] before:

(a) importing the dangerous goods;

(b) offering the dangerous goods for transport; or

(c) handling or transporting the dangerous goods, in the case where no other person is required to have an [ERAP] in respect of that handling or transporting. ${ }^{102}$

The term "offer for transport" is defined in the TDG Regulations ${ }^{103}$ as meaning, "for dangerous goods not in transport, to select or allow the selection of a carrier to transport the dangerous goods, to prepare or allow the preparation of the dangerous goods so that a carrier can take possession of them for transport or to allow a carrier to take possession of the dangerous goods for transport." 104

Further guidance on when an approved ERAP is required is set out in section 7.1 of the TDG Regulations. In particular, section 7.1(8) of the TDG Regulations explains that an ERAP is required where a quantity of dangerous goods exceeds the ERAP limit, which will occur, among other triggers,

if the dangerous goods have an index number in [Column 7] of Schedule 1 and

(a) if solid, have a mass that is greater than the index number when that number is expressed in kilograms;

(b) if liquid, have a volume that is greater than the index number when that number is expressed in litres; [or]

(c) if gas, including a gas in a liquefied form, are contained in a means of containment that has a capacity greater than the index number when that number is expressed in litres. ${ }^{105}$

\section{Ibid, Schedule.}

Ibid, s 7(1).

Supra note 93 .

Ibid, s 1.4 .

Ibid, s 7.1(8). Simply stated, Column 7 of Schedule 1 to the TDG Regulations, ibid, gives the ERAP quantity limit above which a TDG Regulations approved ERAP is required for the dangerous goods in accordance with section 7.1 of Part 7 of the TDG Regulations. Additional guidance is provided in Transport Canada, "Schedule 1 - Legend - TDG Act \& Regulations" (29 September 2017), online: $<$ wwwapps.tc.gc.ca/Saf-Sec-Sur/3/sched-ann/legend-schedule1.aspx $>$. 
Additionally, of particular note to the oil and gas industry, section 7.1(6) provides that "[a] person who imports or offers for transport any of the following dangerous goods by rail in a tank car must have an approved ERAP if the quantity of the dangerous goods in the tank car exceeds 10000 L" "106: Petroleum crude oil (UN1267), petroleum distillates (UN1268), liquid hydrocarbons (UN3295), or petroleum sour crude oil (UN3494), among others.

An ERAP must outline "what is to be done to respond to an actual or anticipated release of the dangerous goods in the course of their handling or transporting that endangers, or could endanger, public safety." 107 Further particulars as to what must be included in the ERAP are set out in section 7.2(2) of the TDG Regulations, which provides that an application for approval of an ERAP must be signed by the person submitting it and must include, among other things:

- the classification of the dangerous goods to which the ERAP relates;

- the type and size of the means of containment used to transport the dangerous goods to which the ERAP relates;

- the geographical area covered by the ERAP;

- the telephone number, including the area code, to call to have the ERAP activated immediately;

- a description of the emergency response capabilities available to the person offering for transport or importing dangerous goods including: (i) the number of persons qualified to give, by telephone, technical advice about the dangerous goods, (ii) the number of persons qualified and available to give advice and assistance at the site of an emergency, (iii) a list of the specialized equipment that can be transported to and used at the site of an emergency, (iv) a general description of the response actions capable of being taken at the site of an emergency, (v) a description of the transportation arrangements to bring specialized emergency response personnel and equipment to the site of an emergency, and (vi) a description of the communications systems that can be made available at the site of an emergency;

- a potential accident assessment including (i) a general analysis of how an accidental release of dangerous goods could occur, (ii) a general description of the potential consequences of an accidental release of dangerous goods, and (iii) a description of the action the applicant is expected to take in the event of an accidental release or an imminent accidental release of dangerous goods; and

- a copy of any formal agreement with a third party for the provision of assistance. ${ }^{108}$

\section{b. Incident Reporting Obligations}

Section 18(1) of the TDGA provides that "[a]ny person who has the charge, management or control of a means of containment shall report ... any actual or anticipated release of dangerous goods that is or could be in excess of a quantity or concentration specified by regulation from the means of containment if the release endangers, or could endanger, public safety." ${ }^{109}$ Section 18(2) further states that "[e]very person required to make a report shall, as soon as possible in the circumstances, take all reasonable emergency measures to reduce or eliminate any danger to public safety that results or may reasonably be expected to result 
from the release." 110 The information to be reported is set out in the TDG Regulations. Specifically, sections 8.2 to 8.8 govern emergency reports for road, rail, or marine transport.

\section{Pursuant to section 8.2 of the TDG Regulations,}

[a] person who is required ... to report a release or anticipated release of dangerous goods that are being offered for transport, handled or transported by road vehicle, railway vehicle or ship must, as soon as possible after a release or anticipated release, make an emergency report to any local authority that is responsible for responding to emergencies at the geographic location of the release or anticipated release if the dangerous goods are, or could be, in excess of the quantity [set out in the table provided in section 8.2 of the TDG Regulations]. ${ }^{111}$

Notably, reporting requirements, including the reporting thresholds set out in this table, were amended in June of 2016 and, for most classes and packing categories (except category III), any quantity released must now be reported. ${ }^{112}$ The information to be included in an emergency report is outlined in section 8.3 of the TDG Regulations.

As soon as possible after making the emergency report, that person must then also make a "release or anticipated release report" to CANUTEC and the consignor of the dangerous goods if the release (or anticipated release) resulted in (a) the death of a person; (b) a person sustaining injuries that required immediate medical treatment by a health care provider; (c) an evacuation of people or their shelter in place; or (d) the closure of a facility used in the loading and unloading of dangerous goods, or a road, a main railway line, or main waterway. ${ }^{113}$ Even if the foregoing results were not sustained, a release or anticipated release report must also be made if

(a) a means of containment has been damaged to the extent that its integrity is compromised; or

(b) the centre sill or stub sill of a tank car is broken or there is a crack in the metal equal to or greater than $15 \mathrm{~cm}^{114}$

The information to be included in a release or anticipated release report is outlined in section 8.5 of the TDG Regulations. Within 30 days of making a release or anticipated release report, a written follow-up report must be made to the Director General. ${ }^{115}$ The detailed information to be included in the follow-up report is set out in section 8.7 of the TDG Regulations and includes, among numerous other details, "an estimate of any financial loss incurred as a result of the release or anticipated release, and any emergency response cost or remediation costs related to it." 116 Finally, the person "must keep a copy of the report for two years after the day on which it is made," and "make the report available to an inspector within 15 days after the day on which the person receives a written request from the inspector."117

Ibid, s 18(2).

TDG Regulations, supra note 93, s 8.2.

Ibid. See also the Regulatory Impact Analysis Statement accompanying these amendments, SOR/201695 (Regulatory Impact Analysis Statement), (2016) C Gaz II, 1183 (Transportation of Dangerous Goods Act, 1992), online: <www.gazette.gc.ca/rp-pr/p2/2016/2016-06-01/html/sor-dors95-eng.php>. TDG Regulations, ibid, ss 8.4(1)-(2).

Ibid, s 8.4(3).

Ibid, s 8.6

Ibid, s $8.7(\mathrm{~s})$.

Ibid, ss 8.8(2)-(3). 


\section{B. Alberta}

1. OIL AND GAS CONSERVATION ACT, OIL SANDS

CONSERVATION ACT, AND PIPELINE ACT (DIRECTIVE 071:

EMERGENCY PREPAREDNESS AND RESPONSE)

a. Emergency Response Planning Obligations

Whether a company's oil and gas operations are licensed by the AER pursuant to the Oil and Gas Conservation Act ${ }^{118}$ and associated Oil and Gas Conservation Rules, ${ }^{119}$ the Oil Sands Conservation Act ${ }^{120}$ and associated Oil Sands Conservation Rules, ${ }^{121}$ or the Pipeline Act ${ }^{122}$ and associated Pipeline Rules, ${ }^{123}$ every licensee must, at a minimum, have a corporatelevel Emergency Response Plan (ERP) that covers all of its operations in Alberta. ${ }^{124}$ The AER's Directive 071: "Emergency Preparedness and Response"125 defines (i) when particular types of ERPs are needed; (ii) ERP content requirements and maintenance schedules; (iii) public and government agency involvement; (iv) consultation and notification requirements; (v) frequency of ERP exercises; and (vi) directions on calculating emergency planning zones (EPZs) and emergency response zones. ${ }^{126}$ Directive 071 is separated into two parts: Part A provides the planning requirements for ERP development that licensees must meet, ${ }^{127}$ and Part B provides requirements that licensees must meet in order to effectively implement their plans and respond to an emergency. ${ }^{128}$

In addition to corporate ERPs, site-specific ERPs are required for certain facilities, including for each sour well, ${ }^{129}$ sour production facility and associated gathering system, ${ }^{130}$ and hydrocarbon storage cavern. ${ }^{131}$ All licensees that are required to submit either a general corporate, sour well, sour production facility and associated gathering system, or cavern ERP must ensure that the respective ERP is updated and must undertake training exercises in accordance with Directive $071 .^{132}$ In the case of an emergency, licensees must report the emergency to the AER and implement the ERP in accordance with Directive $071 .{ }^{133}$ The operator of an oil sands site must also prepare an ERP to be followed "when handling gas with a hydrogen sulphide content greater than 10 moles per kilomole"; "in the event of an uncontrolled emission of contaminants to the air, water or land"; or "in the event of a fire." 134

RSA 2000, c O-6 [OGCA].

Alta Reg 151/1971 [OGC Rules].

RSA 2000, c O-7 [OSCA].

Alta Reg 76/1988 [OSC Rules].

RSA 2000, c P-15.

Supra note 24.

OGC Rules, supra note 119, s 8.002(1); OSC Rules, supra note 121, s 8; Pipeline Rules, ibid, s 8.

Alberta Energy Regulator, "Emergency Preparedness and Response Requirements for the Petroleum Industry" (Calgary: AER, 2017) [Directive 071].

An EPZ is a "geographical area surrounding a well, pipeline, or facility containing hazardous product that requires specific emergency response planning." An EPZ "is used for planning purposes and reflects an area where significant exposure could result.... [R] esponse zones are where resources are focused during an incident to protect public safety" (Directive 071, ibid at 54).

Ibid at $11-50$.

Ibid at 51-76.

OGC Rules, supra note 119 , ss $8.003(1)-(2)$

Ibid, ss 8.004(1)-(2)

Ibid, ss 8.005(a)-(b).

Ibid, s 8.006(a).

Ibid, s 8.006(b).

OSC Rules, supra note 121 , s 8. 
Where pipelines are concerned, in addition to corporate ERPs, site-specific ERPs are required for pipelines conveying HVP product, ${ }^{135}$ and pipelines conveying hydrogen sulphide gas in the gas phase when the pipeline is operating if any surface development exists or is taking place within the EPZ calculated in accordance with Directive 071. ${ }^{136}$ The licensee must update all pipeline ERPs, conduct training exercises, and ensure that it is capable of adequately responding to spills, in accordance with Directive $071 .{ }^{137}$

Spill preparedness requirements apply to all wells (except suspended wells and gas wells that produce less than 2 cubic metres of hydrocarbon liquids per month). Licensees are exempt, however, from the requirements to develop their own spill response plans, purchase their own spill cleanup equipment, and conduct annual exercises if they are active members in good standing of an oil spill cooperative in Alberta for the area in which their operations are located. ${ }^{138}$

In Appendix 4 to Directive 071, the AER provides a method of classifying incidents and response actions for certain specific incidents to assist in the communication to others in industry, local authorities, health authorities, and government agencies in a consistent manner. Incidents are classified either as an alert, or as a level-1, level-2, or level-3 emergency. ${ }^{139}$ If the incident is very low risk and can be handled onsite through normal operating procedures, the AER classifies this as an "alert." Incidents with low to high risk that require a more complex resolution are classified as "emergencies," with 1 being the lowest risk level and 3 being the highest. ${ }^{140}$

Effective 2 February 2017, all ERPs must now be submitted electronically through the AER's Digital Data Submission system, rather than by hard copy. ${ }^{141}$ Once ERPs are approved, they become public documents and may be disclosed with the exception of any confidential resident and personal information. ${ }^{142}$ The AER no longer requires the submission of annual ERP updates for approval, but monitors ERP accuracy through its emergency response assessment program. In addition to updating its ERPs on a semi-annual basis for such matters as new resident information, changes to response staff information, and facility

135 Pipeline Rules, supra note 24, s 8(2).

Ibid, ss 8(3)-(4).

Ibid, s 8(6).

Directive 071, supra note 125, s 10.1 .

Ibid at 101 . See also ibid at 80 , where the three levels of emergencies beyond a mere "alert," which is an incident that can be handled on site by the licensee through normal operating procedures, are defined as follows:

[L] evel 1 emergency: There is no danger outside the licensee's property, there is no threat to the public, and there is minimal environmental impact. The situation can be handled entirely by licensee personnel. There will be immediate control of the hazard. There is little or no media interest.

level 2 emergency: There is no immediate danger outside the licensee's property or the rightof-way, but there is the potential for the emergency to extend beyond the licensee's property. Outside agencies must be notified. Imminent control of the hazard is probable but there is a moderate threat to the public and/or the environment. There may be local and regional media interest in the event.

level 3 emergency: The safety of the public is in jeopardy from a major uncontrolled hazard. There are likely significant and ongoing environmental impacts. Immediate multiagency municipal and provincial government involvement is required.

$140 \quad$ Ibid at 13,25

141 Alberta Energy Regulator, "Change to Submission of Emergency Response Plans under Directive 071: Emergency Preparedness and Response Requirements for the Petroleum Industry" (Calgary: AER, 2017) at 1, online: <www.aer.ca/documents/bulletins/Bulletin-2017-03.pdf>. 
additions, the licensee must also conduct a public awareness program every second year with residents within the EPZ, if applicable. As part of the program, the licensee is expected to provide an updated public information package to each resident. ${ }^{143}$ The licensee must test its ERP by conducting annual tabletop or communications exercises, and by conducting a major exercise once every three years. ${ }^{144}$

Unsurprisingly, the failure to meet many of the requirements set out in Directive 071 are assessed by the AER as high risk non-compliances, including such matters as (i) failing "to contact the AER after activating internal response resources to confirm the level of emergency and convey the specifics of the incident"; (ii) failing "to ensure that a call to the licensee 24-hour emergency telephone number initiates immediate action"; (iii) failing to "review the corporate-level ERP with personnel assigned roles and responsibilities"; and (iv) failing "to provide training sessions to ensure that response personnel are competent in emergency response procedures."145

\section{b. Incident Reporting Obligations}

Emergency response requirements are set out in Part B of Directive 071. Further, in addition to the release reporting obligations under the Environmental Protection and Enhancement Act, ${ }^{146}$ which are discussed further below, there are a number of reporting obligations under the OGCA, the OSCA, and the Pipeline Act, as well as the rules thereunder. Notably, the AER released a guide of frequently asked questions in respect of release reporting in April 2017, which pulls together the various reporting requirements and provides some guidance as to how the AER interprets them. ${ }^{147}$

In accordance with the OGC Rules, "[w] hen oil, water or unrefined product is spilled or released from a break or leak in a wellhead, tank, separator, treater or process vessel, the licensee of the well or operator of the facility from which the spill or release occurred shall immediately take reasonable steps to contain and clean up the spill or release." ${ }^{148}$ The licensee must "immediately orally report the size and location of the spill" to the AER's 24hour emergency line ${ }^{149}$ where the spill or release "is not confined to the site of the well or facility from which the spill or release occurred" (that is, has migrated offsite), "is on-site and is in excess of 2 cubic metres," or "is on-site and of a size that may cause, is causing or has caused an adverse effect as defined in the [EPEA]." ${ }^{150}$ Similar reporting and cleanup is also required "[w]here oil, water or unrefined product is spilled while being transported,

$143 \quad$ Ibid at 67

$144 \quad$ Ibid at 68

145 Alberta Energy Regulator, "AER Table of Noncompliant Events and Associated Risk Rating of AER Requirements" (Calgary: AER, 2016) at 27, 29, online: <www.aer.ca/documents/enforcement/Risk AssessedNoncompliances.pdf $>$.

146 RSA 2000, c E-12 [EPEA].

147 Alberta Energy Regulator, "Frequently Asked Questions: Release Reporting" (Calgary: AER, 2017), online: <www.aer.ca/documents/forms/FAQ_Release_Reporting.pdf>. See also Alberta Energy Regulator, "Release Reporting Requirements"(Calgary: AER, 2016), online: <www.aer.ca/documents/ directives/AER-ReleaseReportingBrochure.pdf>.

OGC Rules, supra note 119 , s 8.050(1).

Ibid, s 8.050(2). At the time of writing, that number is 1-800-222-6514.

Ibid. Note that if the licensee fails to take steps the AER considers necessary to contain and clean up the escaped substance and to prevent further escapes, the AER may enter on the area where the substance has escaped and conduct any operations it considers necessary (OGCA, supra note 118, ss 41, 104). 
otherwise than by pipeline, from a well, pipeline or other facility over which the [AER] has jurisdiction." "I51 In addition to reporting the release to the emergency line at the first available opportunity after becoming aware of the release, licensees are also required to file a written release report within seven days of the release with the appropriate AER field centre. ${ }^{152}$ The AER has developed a particular release report form to be used for this purpose. ${ }^{153}$

Reporting is also required of

(a) any fire that occurs at a well, facility, in situ coal scheme or at an oil sands oil storage tank or pit owned or operated by the licensee, approval holder or operator where the loss exceeds 2 cubic metres of oil or 30000 cubic metres of gas or where damage to the well head occurs,

(b) any break or leak in a vessel or gathering line from which the loss exceeds 30000 cubic metres of gas, or

(c) any unexplained loss, including theft of oil at a well, facility, in situ coal scheme or oil sands facility, where the loss exceeds 2 cubic metres of oil, condensate or crude bitumen. ${ }^{154}$

Under the OSC Rules, the operator at an oil sands site must report by the quickest effective means to the AER (that is, the AER's 24-hour emergency line)

(a) any liquid spill,

(b) any break or leak in a vessel or gathering line or other equipment that occurs at an oil sands site where the loss exceeds 2 cubic metres of liquid hydrocarbon or 30000 cubic metres of gas or gas equivalent or where significant damage to equipment occurs, and

(c) any fire that occurs at an oil sands site, including the sulphur storage block or handling facility, that requires or results in the deployment of major fire-fighting equipment and resources. ${ }^{155}$

Thereafter, the AER may require, within two weeks of the AER's direction, a full written report in accordance with the requirements set out in section 13(2) of the OSC Rules. ${ }^{156}$

Finally, the Pipeline Act identifies reportable events associated with "pipelines," as defined under that $A c t .{ }^{157}$ In particular, the licensee must immediately inform the AER if a leak or break occurs in a pipeline, ${ }^{158}$ or if "any ground disturbance [results] in a puncture or crack in the pipeline or in a scratch, gouge, flattening or dent on the surface of the pipeline, or in damage to its protective coating." 159 In addition, the licensee must, in accordance with section 10.3.6 of CSA Z662-15, Oil and Gas Pipeline Systems, investigate damage incidents related to external interference and failure incidents to determine their causes and must identify and implement measures to prevent the occurrence of incidents due to similar

$151 \quad$ OGC Rules, ibid, s 8.051.

152 Ibid, s 8.050(3); Release Reporting Regulation, Alta Reg 117/1993, s 4 [RRR]. The RRR is enacted under the EPEA, which we address in further detail below.

153 Alberta Energy Regulator, "Release Report" (Calgary: AER, 2017), online: <www.aer.ca/documents/ forms/AER_ReleaseReport.docx>.

OGC Rules, supra note 119, s 12.140(1).

OSC Rules, supra note 121, s 13(1).

Ibid, s 13(2).

The definition of pipeline is set out in Pipeline Act, supra note 122, s 1(1)(t).

Ibid, s 35(1).

Ibid, s 35(2). 
causes. ${ }^{160}$ Particular requirements regarding what associated records the operating company must ensure are prepared and retained as long as the affected portion of the pipeline system remains in operation are set out in section 10.4.4 of CSA Z662-15. ${ }^{161}$

The AER typically requires that a release report (in a prescribed form) be submitted by the licensee within seven days of the initial report and may require a further full written report, which may include a report generated under the above-noted sections of CSA Z662-15 in accordance with the requirements set out in section 76 of the Pipeline Rules. ${ }^{162}$ "If oil, salt water or other deleterious liquids escape from a leak or break in a pipeline, the licensee shall ... take immediate steps to stop the source of release and contain and clean up the spill."163 The AER may also wish to review the licensee's repair plan and has the authority to specify the method of repair under section 78 of the Pipeline Rules. The AER also recently released Bulletin 2017-09, which establishes new processes for the reporting of non-emergency surface and subsurface releases associated with horizontal directional drilling during pipeline construction. ${ }^{164}$

\section{ENVIRONMENTAL PROTECTION AND ENHANCEMENT ACT}

\section{a. Emergency Response Planning Obligations}

Since the enactment of the Responsible Energy Development Act ${ }^{165}$ and associated amendments to Alberta's energy and environmental legislation, the former Energy Resources Conservation Board has been transformed into the AER, which has also assumed jurisdiction over environmental and public lands legislation previously administered by Alberta Environment and Sustainable Resource Development (now Alberta Environment and Parks) where such legislation applies to "energy resource activities." 166 Emergency response planning obligations in respect of energy resource activities are chiefly addressed in the energy resources enactments discussed in the section above. Where, however, an oil and gas activity is one also requiring approval pursuant to the EPEA, the applicant's emergency response plan will also be considered from an environmental perspective in accordance with the Approvals and Registrations Procedure Regulation. ${ }^{167}$

Supra note 24. This standard is made applicable in Alberta pursuant to the Pipeline Rules, supra note 24 , s $9(2)$.

CSA Z662-15, ibid at 285 .

In many instances of pipeline leaks or failures, completion of the AER's Release Report, supra note 153 will be considered sufficient by the AER.

Pipeline Rules, supra note 24, s77. In addition, if the AER is concerned that the substance may not otherwise be contained and cleaned up immediately, the AER may "enter on the area where the substance has escaped and conduct any operations it considers necessary to contain and clean up the substance" (Pipeline Act, supra note 122, s 36(1)(b)).

See Alberta Energy Regulator, "Bulletin 2017-09: Reporting Non-Emergency Releases from Pipeline Horizontal Directional Drilling" (Calgary: AER, 2017), online: <www.aer.ca/documents/bulletins/ Bulletin-2017-09.pdf $>$. Notably, certain criteria must be met in order for the release to be considered non-emergency and a separate form for the monthly reporting on non-emergencies has been developed. SA 2012, c R-17.3 [REDA].

An "energy resource activity" is defined under section 1(1)(i) of REDA, ibid, as activities that are approved by the AER under "energy resource enactments," which include the OGCA, OSCA, and the Pipeline Act, among others.

Alta Reg 113/1993. 
b. Incident Reporting Obligations

In addition to the incident reporting obligations under the energy resource enactments addressed in the section above, there are also release reporting obligations under section 110 of the EPEA, which are to be reported in accordance with the requirements of the $R R R \cdot{ }^{168} \mathrm{In}$ particular, any person "who releases or causes or permits the release of a substance into the environment that may cause, is causing or has caused an adverse effect shall, as soon as that person knows or ought to know of the release, report it" to the AER. ${ }^{169}$ Adverse effect is defined broadly as meaning any "impairment of or damage to the environment, human health or safety or property." $" 170$

When reporting a release under the $R R R$, the person reporting the release is required to provide certain prescribed information, including: details regarding the timing and location of the release; a "description of the circumstances leading to the release"; and "the details of any action proposed or taken at the release site." ${ }^{171}$ Within seven days thereafter, the person reporting the release is required to submit a release report that includes certain prescribed information, including details regarding the timing, location, duration, and composition of the release; "a detailed description of the circumstances leading up to the release"; "the steps or procedures that were taken to minimize, control or stop the release"; and "the steps or procedures which will be taken to prevent similar releases." 172

To avoid duplication of reporting obligations, section 2 of the $R R R$ provides that sections 110 to 112 of the EPEA do not apply "to releases of substances that are regulated by the [OGCA] or any regulation made under that Act, the Dangerous Goods Transportation and Handling Act or any regulation made under that Act, or an approval, licence or permit granted under any of those Acts or regulations." obligations do not apply "to releases of substances classified as Class 1 dangerous goods (explosives) or Class 7 dangerous goods (radioactive materials) as set out in the Schedule to the [TDGA]." 174 Section 3 of the RRR, however, goes on to explain that where a release of a substance falling within the Class set out in the first column of the Table in section 8.1(1) (now 8.2) of Part 8 of the TDG Regulations under the TDGA occurs and the release has caused, is causing, or may cause an adverse effect, sections 110 to 112 of the EPEA do apply if the release is in excess of the level specified in the TDG Regulations or if the substance is released into a watercourse or into groundwater or surface water. In other words, in addition to the reporting requirements under the TDG Regulations, releases of substances captured under those federal regulations must also be reported to the AER when they exceed the applicable threshold or are into water sources.

Supra note 152 . The RRR sets out what must be reported, and when and how reports should be made. EPEA, supra note 146, s 110(1).

Ibid, s 1(b).

Alberta Environment, “A Guide to Release Reporting” (Edmonton: AE, 2005) at 5, online: <aep.alberta. ca/air/legislation/air-monitoring-directive/documents/GuideReleaseReporting-2005.pdf>.

Ibid at 7; RRR, supra note 152 , s 4(3). These reports can now be made to the AER by completing and filing the Release Report, supra note at 153.

$R R R$, ibid, s 2(a).

Ibid, s 2(b). 


\section{DANGEROUS GOODS TRANSPORTATION AND HANDLING ACT}

The Dangerous Goods Transportation and Handling Act ${ }^{175}$ is administered by ATDG, which operates the Co-ordination and Information Centre (CIC), a 24-hour emergency response centre for the reporting of accidental or imminent accidental releases of dangerous goods during any aspect of transport. Notably, the federal TDG Regulations are adopted pursuant to section 2 of the Dangerous Goods Transportation and Handling Regulation. ${ }^{176}$ Accordingly, the requirements relating to emergency response planning and release reporting are consistent in both jurisdictions.

\section{a. Emergency Response Planning Obligations}

In accordance with section 21(1) of the DGTHA, "[b]efore offering for transport any prescribed quantity or concentration of dangerous goods, a person shall have an emergency response assistance plan ... that outlines what is to be done if there is an accident in transporting the dangerous goods." "Th7 The Minister may "approve the plan, either indefinitely or for a specified period, if the Minister believes on reasonable grounds that it is capable of being implemented and will be effective in responding to any accident in transporting the dangerous goods." 178 The Minister may revoke the approval if the Minister "has requested changes to the plan that are believed on reasonable grounds to be needed to make it effective and the changes have been refused or have not been made," or "believes on reasonable grounds that the plan is no longer capable of being implemented."179 The prescribed circumstances for which an ERAP is required, and the matters to be addressed in the ERAP, are the same as described above and as set out in Part 7 of the TDG Regulations.

\section{b. Incident Reporting Obligations}

Pursuant to section 13(1) of the DGTHA, "[w] here a release of dangerous goods in excess of a prescribed quantity or concentration occurs or is imminent from a means of containment being used to handle or transport dangerous goods, any person who at the time has the charge, management or control of the means of containment" ${ }^{\prime 180}$ must immediately report the matter. The prescribed quantity or concentration triggering this reporting obligation along with the manner of reporting and content of the report are all as described above and as set out in Part 8 of the federal TDG Regulations. ${ }^{181}$ In addition to reporting, the person who at the time has the charge, management, or control of the means of containment must also "take all reasonable emergency measures to reduce or eliminate any danger to public safety that results or that may reasonably be expected to result from the release." 182 In Alberta, initial

RSA 2000, c D-4 [DGTHA].

Alta Reg $157 / 1997$.

Supra note 175, s 21(1).

Ibid, s 21(2).

Ibid, s 21(4).

Ibid, s 13(1).

In particular, the prescribed quantity triggering the reporting obligation is set out in the table appearing in section 8.2 of the TDG Regulations, supra note 93. Requirements for emergency reports are set out in section 8.2 and requirements for release or anticipated release reports are set out in sections 8.4-8.5. See also Alberta Transportation, "Emergency, Release or Anticipated Release Report Requirements" (Edmonton: AT, 2017), online: $<$ https://www.transportation.alberta.ca/Content/docType272/Production/ reporting.pdf $>$. 
emergency reporting should be to the CIC. ${ }^{183}$ Thereafter, the release or anticipated release report should be to CANUTEC and the consignor. The 30-day follow-up reporting obligations also apply. ${ }^{184}$

\section{FoREST AND PRAIRIE PROTECTION ACT}

\section{a. Emergency Response Planning Obligations}

The devastation of last year's wildfires in Fort McMurray, which prompted the largest wildfire evacuation in Alberta's history, is a stark reminder of the importance of the Industrial Wildfire Control Plan (IWCP) requirements set out in the Forest and Prairie Protection Act. ${ }^{185}$ The intent of the IWCP is to provide information to Alberta's Agriculture and Forestry Ministry (AF) as to where employees are working full time, and to increase employee safety in the event of an emergency wildfire. ${ }^{186}$ Pursuant to section 23(1) of the FPPA, "[a] person carrying on or having charge of an industrial or commercial operation on public land or within one kilometer of any public land shall at the request of a forest officer submit a fire control plan ... within the time determined by the forest officer." ${ }^{187}$ If the person fails to submit the IWCP at the time determined, the Minister may "suspend the industrial or commercial operation ... until a fire control plan satisfactory to the forest officer has been submitted." 188 IWCP submissions are mandatory under the FPPA for all "facilities located on or within one kilometer of public land and inhabited by at least one person for four or more hours in a day" (non-consecutive), during March 1 through November 31. ${ }^{189}$

As part of the IWCP, when describing a company's various sites, "[i]f a facility has equipment on site that can be used to support AF wildfire suppression efforts, AF requests that companies include information about the equipment (type and quantity) in the site details." 190 As with site equipment, AF further requests that relevant water upgrade information be provided in the event it could be used for fire suppression. Water upgrades includes ponds, dugouts, water wells, and the like. ${ }^{191}$ Each year on 28 February, all IWCPs must be reactivated and updated for the duration of the fire season. As of 31 December, all IWCPs are "automatically ... deactivated and IWCP users will have two months to update, reactivate or delete old plans for the next year's fire season."192

\section{b. Incident Reporting Obligations}

Under section 18(3) of the FPPA, if a person "knows or has reason to believe that there is an outdoor fire, not authorized by a permit issued to the person, on land that is ... owned

At the time of writing, CIC's emergency phone number is 1-800-272-9600.

TDG Regulations, supra note 93, ss 8.6, 8.7.

RSA 2000, c F-19, s 23 [FPPA].

Alberta Agriculture and Forestry, "Industrial Wildfire Control Plan" (10 March 2017), online: < wildfire. alberta.ca/prevention/industry/industrial-wildfire-control-plan.aspx $>$.

FPPA, supra note 185, s $23(1)$.

Ibid, s 23(2).

Alberta Agriculture and Forestry, "Industrial Wildfire Control Plan User Manual (IWCP)" (17 August 2016) at 1, online: < wildfire.alberta.ca/prevention/industry/documents/IndustrialWildfire ControlPlanAug2016.pdf $>$.

Ibid at 27.

Ibid at 28

Ibid at 39. 
or occupied by the person or under the person's control," the person must extinguish the fire if possible or "immediately report the fire to a forest officer, an employee of the municipality in which the fire is located or a member of the Royal Canadian Mounted Police." ${ }^{\prime 193}$

\section{OCCUPATIONAL HEALTH AND SAFETY ACT}

\section{a. Emergency Response Planning Obligations}

The OHSA ${ }^{194}$ and the Occupational Health and Safety Code $2009^{195}$ set out the health and safety obligations applicable in Alberta's oil and gas workplaces, including the obligation that employers have an ERP. Part 7 of the OHS Code governs emergency preparedness and response in the workplace. Employers are required to establish an ERP for an emergency that may require either a rescue or an evacuation. ${ }^{196}$ Section 8 of the Occupational Health and Safety Regulations ${ }^{197}$ requires any plan governed by the OHSA, including an ERP, to be in writing, and a copy of the plan must be available to workers. The ERP is intended to establish "what the employer must do until emergency services personnel arrive."198 Additionally, employers are directed to consult with affected workers in establishing the $\mathrm{ERP}^{199}$ and must subject the ERP to regular review to ensure that it is current. ${ }^{200}$

As outlined in the AOHS, "Guide," a complex ERP will be required at workplaces containing hazardous materials or "at workplaces where workers fight fires, perform rescue and medical tasks, or evacuation ... is delayed as workers shut down critical equipment" (such as at oil and gas facilities). ${ }^{201}$ The Guide also cautions that in some situations, local rescue services personnel "may not have the equipment or skills to perform a rescue." ${ }^{202}$ In these cases, "the employer's on-site rescue capability must be such that the work site is virtually self-sufficient in returning a rescued worker [to safety]."203

Section 116 of the OHS Code sets out the following minimum requirements of what is required for the contents of the plan, each of which must be addressed on a site-specific basis to include additional items specific to the operations of individual work sites:

(a) the identification of potential emergencies;

(b) procedures for dealing with the identified emergencies;

(c) the identification of, location of and operational procedures for emergency equipment;

(d) the emergency response training requirements;

Supra note 185, s 18(3).

Supra note 67.

Alberta, Occupational Health and Safety Council, Occupational Health and Safety Code 2009 (Alberta: Queen's Printer, 2009) [OHS Code]. The OHS Code was adopted pursuant to the Occupational Health and Safety Code 2009 Order, Alta Reg 87/2009.

OHS Code, ibid, s 115(1).

Alta Reg 62/2003.

Alberta Occupational Health and Safety, "OHS Code Explanation Guide: Part 7 Emergency Preparedness and Response - Section 115 Emergency Response Plan" (1 July 2009), online: <https:// work.alberta.ca/SearchAARC/1053.html> [AOHS, "Guide"].

OHS Code, supra note 195, s 115(2).

Ibid, s 115(3).

AHOS, "Guide," supra note 198.

Ibid.

Ibid. 
(e) the location and use of emergency facilities;

(f) the fire protection requirements;

(g) the alarm and emergency communication requirements;

(h) the first aid services required;

(i) procedures for rescue and evacuation; [and]

(j) the designated rescue and evacuation workers. ${ }^{204}$

Pursuant to section 117 of the OHS Code, employers must also designate certain workers who will "provide rescue services and supervise evacuation procedures in an emergency."205 Accordingly, employers must "ensure that designated rescue and emergency workers are trained in emergency response appropriate to the work site and the potential emergencies identified in the [ERP]. ${ }^{.206}$ The OHS Code also mandates that the training provided to these designated employees must "include exercises appropriate to the work site that simulate the potential emergencies identified in the [ERP]." ${ }^{.07}$ Training exercises "must be repeated at intervals required to ensure that the designated rescue and evacuation workers are competent to carry out their duties." 208 AOHS has outlined the necessary considerations for employers when creating ERPs in "Building an Effective Health and Safety Management System."209

\section{b. Incident Reporting Obligations}

The time, place, and nature of any of the following serious injuries and accidents that occur at a work site must be reported as soon as possible to the Director of Inspection: ${ }^{210}$

(a) an injury or accident that results in death,

(b) an injury or accident that results in a worker's being admitted to a hospital for more than 2 days,

(c) an unplanned or uncontrolled explosion, fire or flood that causes a serious injury or that has the potential of causing a serious injury,

(d) the collapse or upset of a crane, derrick or hoist, or

(e) the collapse or failure of any component of a building or structure necessary for the structural integrity of the building or structure. ${ }^{211}$

Except as is necessary to attend to anyone who has been injured or killed, to prevent further injuries, and to protect property that is endangered as a result of the accident, the scene of a reported injury or accident must not be disturbed. ${ }^{212}$

In addition to reporting the injury or accident, the prime contractor, contractor, or employer responsible for the work site where the injury or accident occurred must also

OHS Code, supra note 195, s 116. When identifying potential emergencies, the ERP must address all of the emergencies identified in the work site hazard assessment required under Part 2 of the OHS Code (ibid).

Ibid, s 117(1).

Ibid, s 117(2).

Ibid, s 117(3).

Ibid, s 117(4).

Alberta Occupational Health and Safety, "Building an Effective Health and Safety Management System" at 24-26, online: <work.alberta.ca/documents/building-an-effective-health-and-safety-managementsystem.pdf $>$. OHSA, supra note 67 , s $18(1)$.

Ibid, s 18(2).

Ibid, s 18(6). 
(a) carry out an investigation into the circumstances surrounding the serious injury or accident,

(b) prepare a report outlining the circumstances of the serious injury or accident and the corrective action, if any, undertaken to prevent a recurrence of the serious injury or accident, and

(c) ensure that a copy of the report is readily available for inspection. ${ }^{213}$

Notably, this statutorily-mandated report is "not admissible as evidence for any purpose in a trial arising out of the serious injury or accident, an investigation or public inquiry under the Fatality Inquiries Act or any other action as defined in the Alberta Evidence Act except in a prosecution for perjury or for the giving of contradictory evidence." 214

\section{INSPECTION AND INVESTIGATION PoWERS AND PRACTICES}

In the sections that follow, we have attempted to capture the main pieces of both federal and Alberta legislation pursuant to which oil and gas producers, carriers, and processors may be subject to regulatory compliance audits, inspections, and investigations in the wake of an incident or emergency. What will be immediately apparent to the reader is that regulators have extremely broad powers to, among other things, search premises, request the production of documents, seize records and other items, and to compel statements from the operator's employees and agents. Unlike in the criminal law sphere, where rights including those against unreasonable search and seizure and against self-incrimination are guaranteed under the Charter and frequently engaged, the courts have taken a more restrictive approach in the regulatory sphere. ${ }^{215}$ This has occurred largely on the basis that participation in regulated activities or industries is a choice and monitoring compliance is not adversarial. ${ }^{216}$ Additionally, the expectation of privacy in a regulated workplace or environment is typically diminished. ${ }^{217}$ We explore these issues in further detail in Part IV, below.

While we also address issues relating to claims of legal privilege in more detail in Part IV, the reader should bear in mind that the powers of the various regulators relating to document disclosure and statements outlined in this Part are not unlimited. In each case, those powers are subject to appropriate claims of legal privilege over certain documents. In light of the Supreme Court of Canada's recent decisions in Alberta (Information and Privacy Commissioner) v. University of Calgary ${ }^{218}$ and Lizotte v. Aviva Insurance Company of

\footnotetext{
$213 \quad$ Ibid, s $18(3)$.

$214 \quad$ Ibid, s $18(5)$.

215 See e.g. Rv Fitzpatrick, [1995] 4 SCR 154 [Fitzpatrick]; Thomson Newspapers Ltd v Canada (Director of Investigation and Research, Restrictive Trade Practices Commission), [1990] 1 SCR 425 [Thomson Newspapers]; $R v$ Wholesale Travel Group Inc, [1991] 3 SCR 154 [Wholesale Travel] (relating to a charge under the Competition Act, RSC 1985, c C-23, distinguishing between "regulatory offences" and "true crimes," and holding that the strict liability regulatory offence requiring only negligence as mens rea did not violate section 7 of the Charter). See also the companion cases of $R v$ Jarvis, 2002 SCC 73, [2002] 3 SCR 757 [Jarvis] and $R v$ Ling, 2002 SCC 74, [2002] 3 SCR 814 [Ling].

216 Fitzpatrick, ibid at paras 35-42.

217 See R v Mission Western Developments Ltd, 2011 BCSC 1378, 64 CELR (3d) 206 at para 30, where the British Columbia Supreme Court held that "property intended for commercial development, a highly regulated use," could not "sustain a reasonable expectation of privacy over the statutory powers of inspection" given to the DFO under the Fisheries Act, RSC 1985, c F-14. Accordingly, no breach of the section 8 Charter right to be secure against unreasonable search or seizure had occurred (at para 43). See also Comité paritaire de l'industrie de la chemise v Potash ; Comité paritaire de l'industrie de la chemise v Sélection Milton, [1994] 2 SCR 406; British Columbia Securities Commission v Branch, [1995] 2 SCR 3. 
Canada ${ }^{219}$ it is now clear that legal privilege can only be abrogated by statute where the intent is expressed through clear, explicit, and unequivocal language. ${ }^{220}$

\section{A. FEDERAL}

\section{THE NATIONAL ENERGY BoARD}

\section{a. National Energy Board Act}

The NEB uses several types of compliance verification activities throughout all the stages of an energy project's, or pipeline's, lifecycle to ensure that companies are compliant with the NEB Act and regulations thereunder. In 2011, the NEB began posting information publicly on its compliance and enforcement activities. Specifically, the Board publishes inspection reports, audits of company operations, inspection officer orders, incident investigation reports, Board Orders, and many other relevant documents and correspondence. ${ }^{221}$

The NEB's investigatory powers are derived from its broad powers under section 12(1) of the NEB Act, which provides that:

The Board has full and exclusive jurisdiction to inquire into, hear and determine any matter

(a) where it appears to the Board that any person has failed to do any act, matter or thing required to be done by this Act or by any regulation, certificate, licence or permit, or any order or direction made by the Board, or that any person has done or is doing any act, matter or thing contrary to or in contravention of this Act, or any such regulation, certificate, licence, permit, order or direction; or

(b) where it appears to the Board that the circumstances may require the Board, in the public interest, to make any order or give any direction, leave, sanction or approval that by law it is authorized to make or give, or with respect to any matter, act or thing that by this Act or any such regulation, certificate, licence, permit, order or direction is prohibited, sanctioned or required to be done. ${ }^{222}$

Section 12(1.1) of the NEB Act further provides that "[t]he Board may inquire into any accident involving a pipeline, ... international power line or other facility ... which is regulated by the Board," and may, at the end of the inquiry, make "findings as to the cause of the accident or factors contributing to it," make "recommendations relating to the prevention of future similar accidents," or make "any decision or order that the Board can make." 223

2016 SCC 52, [2016] 2 SCR 521 [Lizotte].

University of Calgary, supra note 218 at para 2 (regarding solicitor-client privilege); Lizotte, ibid at para 64 (regarding litigation privilege).

Canada, National Energy Board, "Compliance and Enforcement" (29 June 2017), online: $<$ https://www. neb-one.gc.ca/sftnvrnmnt/cmplnc/index-eng.html>.

NEB Act, supra note 3, s 12(1).

Ibid, ss 12(1.1)(a)-(c). 
Inspection officers are designated by the Board under section 49(1) of the NEB Act for purposes including ensuring "the safety and security of the public and of a company's employees," and the "protection of property and the environment." ${ }^{224}$ Inspection officers have the powers set out in section 49(2) of the NEB Act, which include (a) accessing and inspecting any lands or pipeline, including a pipeline that is under construction, any abandoned pipeline, as well as any ground disturbances or pipeline crossings; (b) "[directing] a company or person [causing] a ground disturbance ... to perform any tests [considered] necessary for an inspection," and to "provide [requested] information orally or in writing"; and (c) examining and making "copies of any information contained in any books, records or documents, or in any computer systems, that the inspector believes on reasonable grounds contain any information relating to the design, construction, operation, maintenance or abandonment of a pipeline or to the maintenance of an abandoned pipeline." ${ }^{225}$ In exercising their powers, inspection officers must show their certificate of authority to any person who asks to see it. ${ }^{226}$ Notably, any officer, employee, or agent of a company must give inspection officers all reasonable assistance to enable the officers to carry out their duties. ${ }^{227}$

In the event of an emergency involving an NEB-regulated company, the NEB, as the lead federal agency, will carry out the following, as applicable, as it investigates the incident:

- $\quad$ [ensure] the preservation of failed materials for investigation;

- $\quad$ [observe] the site, equipment, protective systems and wreckage;

- $\quad$ [interview] witnesses and company personnel;

- $\quad$ collect $]$ pertinent information;

- $\quad$ review] documentation;

- $\quad$ [require] operational safety prior to a facility being returned to service;

- [determine] the cause and contributing factors;

- $\quad$ [enforce] compliance to regulations and company commitments;

- [determine] whether existing regulations, codes or enforcement and monitoring programs should be changed; and

- $\quad\left[\right.$ recommend] appropriate enforcement actions. ${ }^{228}$

As noted above in Part II, while the NEB is the lead federal agency for all incidents that involve NEB-regulated facilities or activities, for incidents involving NEB-regulated pipelines, the TSB also has jurisdiction to investigate "pipeline occurrences." 22 As we discuss in further detail below, the TSB solely determines "the cause and contributing factors that led to the incident," while the NEB "conducts a concurrent and co-operative investigation to determine factors relating to regulatory compliance, trends within industry, and actions necessary to prevent similar occurrences." 230

Ibid, s 50 .

Ibid, s 51 .

Canada, National Energy Board, "Responding to Emergencies" (Calgary: NEB, 2017) at 1, online:

$<$ https://www.neb-one.gc.ca/sftnvrnmnt/mrgnc/rspndmrgnc/rspndmrgnc-eng.pdf $>$.

See Part II.A.1.b, above.

National Energy Board, "Responding to Emergencies," supra note 228 at 1. 


\section{b. Canada Oil and Gas Operations Act}

Where investigatory powers are concerned, the COGOA operates in much the same manner as the NEB Act. ${ }^{231}$ The Board has broad powers to "inquire into, hear and determine any matter" relating to a person's compliance with, or contravention of, the COGOA, any regulations, order, or directions made under the COGOA, or any operating licence or authorization issued under the COGOA. ${ }^{232}$ Section 28 of the COGOA further provides that

where a spill or debris or an accident or incident related to any activity to which [the COGOA] applies occurs or is found in any area to which [the COGOA] applies and results in death or injury or danger to public safety or the environment, the Minister [of Natural Resources Canada] may direct an inquiry to be made, subject to the [TSB Act], and may authorize any person that the Minister deems qualified to conduct the inquiry. ${ }^{233}$

Where the spill, debris, accident, or incident is serious, the Minister must direct an inquiry and must "ensure that the person who conducts the inquiry is not employed in a part of the federal public administration for which the Minister is responsible."234 The person who conducts the inquiry must "ensure that, as far as practicable, the procedures and practices for the inquiry are compatible with investigation procedures and practices followed by any appropriate provincial authorities." 235 Additionally, a report together with the evidence and other material that was before the inquiry must be submitted to the Minister as soon as possible after the inquiry and must be published by the Minister within 30 days thereafter. ${ }^{236}$

For purposes of administering and enforcing the COGOA, the NEB must designate safety officers and conservation officers, including a Chief Safety Officer and Chief Conservation Officer. ${ }^{237}$ For purposes of ensuring compliance with the COGOA and the regulations thereunder, these officers may at any reasonable time:

(a) [E]nter any place, including lands, buildings, installations, vessels, vehicles and aircraft, used for any work or activity in respect of which this Act applies, for the purpose of carrying out inspections, examinations, tests or inquiries or of directing that the person in charge of the place carry them out, and the officer may be accompanied by any other person that the officer believes is necessary to help carry out the inspection, examination, test or inquiry;

(b) take photographs or make drawings of any place or thing referred to in this section;

(c) order that any place or thing referred to in this section not be interfered with for a specified period;

(d) require the production, for inspection or copying, of any books, records, documents, licences or permits required by this Act or the regulations;

COGOA, supra note 38 .

Ibid, s 5.31.

Ibid, s 28(1).

Ibid, s 28(1.1).

Ibid, s 28(3).

Ibid, ss 28(4)-(5).

Ibid, s 53. 
(e) take samples or particulars and carry out, or have carried out, any reasonable tests or examinations; and

(f) require the person in charge of the place, or any other person in the place who has knowledge relevant to an inspection, examination, test or inquiry, to furnish information, either orally or in writing, in the form requested. $^{238}$

In exercising their powers, these officers must show their certificate of appointment or designation to the "person in charge of the place" they are entering. ${ }^{239}$ Notably, "the owner ... and every person found in a place" in which the officer is exercising his or her powers must give the officer "all reasonable assistance to enable the officer to carry out [his or her] duties," ${ }^{240}$ and it is an offence to "obstruct or hinder or make a false or misleading statement" to an officer. ${ }^{241}$

\section{c. Canada Labour Code - Part II}

The NEB has entered into a memorandum of understanding with Employment and Social Development Canada - Labour Program (in other words, the federal Ministry of Labour) (ESDC) respecting the application and enforcement of Part II of the CL Code ${ }^{242}$ in the "Federal Oil and Gas Industry." 243 The Federal Oil and Gas Industry is defined as "those works, undertakings or businesses related to the federal Pipeline Industry regulated by the NEB under the [NEB Act] , as well as the Frontier Oil and Gas Industry." ${ }^{244}$ Under the MOU, ESDC remains responsible for the application and enforcement of the CL Code and the investigation of "Hazardous Occurrences" 245 at "the head offices and regional offices of the Federal Oil and Gas Industry," whereas the NEB has been delegated authority and, acting on behalf of the Minister of Labour, takes on those responsibilities "in respect of the Federal Oil and Gas Industry, excluding head and regional offices, subject to the [TSB Act.]"246

Section 5.3 of the MOU clarifies that the delegated authority extends to the exercise of the powers, duties, and functions provided in the CL Code and associated regulations including (i) "routinely visiting work places ... to monitor compliance with the [CL Code]"; (ii) "investigating refusals to work, as provided for by section 129 of the [CL Code]"; (iii) "investigating fatalities, Hazardous Occurrences and complaints in respect of the Federal Oil and Gas Industry"; (iv) "investigating complaints related to health and safety and Hazardous

Ibid, s 54 .

Ibid, s 55 .

Ibid, s 56 .

Ibid, s 57.

Supra note 54.

Memorandum of Understanding between Employment and Social Development Canada and National Energy Board Respecting the Application and Enforcement of the Canada Labour Code, Part II (6 April 2016), online: <https://www.neb-one.gc.ca/bts/ctrg/mmrndm/2016mplmntscldvlpmntcnd-eng.html> [MOU].

MOU, ibid. Pipeline Industry is further defined under the MOU as including "works or activities on or in connection with the transportation of oil or gas through a pipeline, as defined in the National Energy Board Act and is subject to the [Canada Occupational Health and Safety Regulations]" (ibid, s 2). Frontier Oil and Gas Industry is further defined as the "works or activities on or in connection with the exploration or drilling for the production, conservation, processing or transportation of oil and gas in frontier lands, regulated by the NEB primarily under the Canada Oil and Gas Operations Act (COGOA) or the Canada Petroleum Resources Act (CPRA), and subject to the Oil and Gas Operational Safety and Health Regulations" (ibid).

"Hazardous Occurrence" is defined under the MOU as meaning "an accident, occupational disease or other occurrence arising in the course of, or in connection with, the employee's work that has caused, or is likely to cause, injury to the health and safety of an employee or any other person" (ibid). Ibid, s 3.4 
Occurrences in respect of the Federal Oil and Gas Industry"; and (v) "preparing ... prosecution proposal[s] for non-compliances with the [CL Code]" and associated regulations, including working with prosecutors, appearing in court, and giving evidence when required. $^{247}$

Having been delegated the Minister of Labour's inspection and investigation powers under the CL Code, when carrying out those duties the NEB may:

[A]t any reasonable time, enter any work place controlled by an employer and, in respect of any work place, may

(a) conduct examinations, tests, inquiries, investigations and inspections or direct the employer to conduct them;

(b) take or remove for analysis, samples of any material or substance or any biological, chemical or physical agent;

(c) be accompanied or assisted by any person and bring any equipment that the [NEB delegated official] deems necessary to carry out [their] duties;

(d) take or remove, for testing, material or equipment if there is no reasonable alternative to doing so;

(e) take photographs and make sketches;

(f) direct the employer to ensure that any place or thing specified ... not be disturbed for a reasonable period pending an examination, test, inquiry, investigation or inspection in relation to the place or thing;

(g) direct any person not to disturb any place or thing specified ... for a reasonable period pending an examination, test, inquiry, investigation or inspection in relation to the place or thing;

(h) direct the employer to produce documents and information relating to the health and safety of the employer's employees or the safety of the work place and to permit the [NEB delegated official] to examine and make copies of or take extracts from those documents and that information;

(i) direct the employer or an employee to make or provide statements, in the form and manner that the [NEB delegated official] may specify, respecting working conditions and material and equipment that affect the health or safety of employees;

(j) direct the employer or an employee or a person designated by either of them to accompany the [NEB delegated official] while the [NEB delegated official] is in the work place; and

(k) meet with any person in private or, at the request of the person, in the presence of the person's legal counsel or union representative. ${ }^{248}$

The NEB, as the delegate of the Minister, is required to "investigate every death of an employee that occurred in the work place or while the employee was working, or that was the result of an injury that occurred in the work place or while the employee was working."249 Where an inspection of the work place is undertaken, it must

Ibid, ss 5.3(b)-(d), (f)-(g). Section 5.6 of the MOU, however, confirms that under section 144 of the $C L$ Code, "no Delegated Official ... may be required to give testimony in a civil or administrative [proceeding] with regard to information obtained in the Delegated Official's exercise of powers ... except with the written permission of the Minister of Labour" (ibid, s 5.6). 
be done in the presence of

(a) an employee member and an employer member of the work place committee; or

(b) the health and safety representative and a person designated by the employer. ${ }^{250}$

The "person in charge of a work place and every person employed at, or in connection with, a work place shall give all reasonable assistance" to the NEB's delegated official in carrying out the foregoing powers. ${ }^{251}$ Further, "[n]o person shall obstruct or hinder, or make a false or misleading statement" to the NEB's delegated official, ${ }^{252}$ or "prevent an employee from providing information" to the NEB's delegated official. ${ }^{253}$

Finally, in accordance with section 144(5) of the CL Code, "except for the purposes of [Part 2 of the CL Code] or a prosecution under [Part 2 of the CL Code] or unless the Minister is satisfied that the publication or disclosure is in the interest of occupational health and safety or the public interest," 254 publishing or disclosing any information obtained as a result of activities carried out under section 141 of the CL Code is prohibited.

\section{THE TRANSPORTATION SAFETY BOARD}

\section{a. Canadian Transportation Accident Investigation and Safety Board Act}

As noted above, under the TSB Act, the TSB has jurisdiction to investigate the cause and contributing factors of any accident or incident associated with the operation of a pipeline, or any situation or condition that the Board has reasonable grounds to believe could, if left unattended, induce an accident or incident (i.e. pipeline occurrence). ${ }^{255}$ Directors of Investigations, appointed under section 10 of the TSB Act, have exclusive authority to direct and conduct investigations on behalf of the TSB.

The powers of investigators are set out in section 19 of the TSB Act:

Where an investigator believes on reasonable grounds that there is, or may be, at or in any place, any thing relevant to the conduct of an investigation of a [pipeline occurrence], the investigator may ... enter and search [the] place for any such thing, and seize any such thing that is found in the course of that search. ${ }^{256}$

However, an investigator must not do so "without the consent of the person apparently in charge of that place" unless the investigator is exercising those powers "under the authority of a warrant," or "by reason of exigent circumstances, it would not be practical for the investigator to obtain a warrant." 257

Ibid, ss 141.1(1)(a)-(b).

Ibid, s 142(b).

Ibid, s 143(b).

Ibid, s 143.1(b).

Ibid, s 144(5).

TSB Act, supra note 30.

Ibid, s 19(1).

Ibid, s 19(2). 
An investigator under the TSB Act has the power to conduct tests on any thing seized, but must, "to the extent that it is practical and safe to do so and does not unreasonably impede the progress of the investigation," invite and allow the owner of the thing to be present at the test. ${ }^{258}$ The investigator also has the power to exclude persons from particular areas "for the purposes of preserving and protecting any thing involved in" the pipeline occurrence. ${ }^{259}$ Additional powers are set out in section 19(9) of the TSB Act, which provides that an investigator who is investigating a pipeline occurrence may:

(a) where the investigator believes on reasonable grounds that a person is in possession of information relevant to that investigation,

(i) by notice in writing signed by the investigator, require the person to produce the information to the investigator or to attend before the investigator and give a statement ... under oath or solemn affirmation if required by the investigator, and

(ii) make such copies of or take such extracts from the information as the investigator deems necessary for the purposes of the investigation;

(b) where the investigator believes on reasonable grounds that the medical examination of a person who is directly or indirectly involved in the operation of an aircraft, ship, rolling stock or pipeline is, or may be, relevant to the investigation, by notice in writing signed by the investigator, require the person to submit to a medical examination;

(c) where the investigator believes on reasonable grounds that a physician or other health practitioner has information concerning a patient that is relevant to that investigation, by notice in writing signed by the investigator, require the physician or practitioner to provide that information to the investigator; or

(d) where the investigator believes on reasonable grounds that the performance of an autopsy on the body of a deceased person, or the carrying out of other medical examinations of human remains, is, or may be, relevant to the conduct of the investigation, cause such an autopsy or medical examination to be performed and, for that purpose, by notice in writing signed by the investigator, require the person having custody of the body of the deceased person or other human remains to permit the performance of that autopsy or that medical examination. ${ }^{260}$

Provided that an investigator is properly exercising the above-noted powers, a person is prohibited from refusing or failing to produce or provide the information requested, or to submit to the required examinations. ${ }^{261}$

Sections 22 and 23 of the TSB Act address cooperation with other federal government departments and provide for certain observers to be present in the context of an investigation of a pipeline occurrence. In particular, a person may attend as an observer at an investigation if the person has been designated as an observer by the Minister of Transport for a "department having a direct interest in the subject-matter of the investigation."262

Ibid, s 19(5)(b).

Ibid, s 19(6).

Ibid, s 19(9). Further particulars in respect of interviews conducted under section 19(9)(a) are set out in section 9 of the TSB Regulations, supra note 32. Notably, under section 9(2)(b), the person being interviewed is permitted to choose one person to attend with them. This person can, however, be excluded from the interview if their "behaviour or interventions interfere with the proper conduct of the interview" (TSB Regulations, ibid, s 9(4)).

TSB Act, ibid, ss 19(10)-(11).

Ibid, s 23(2)(b). Part 2 of the TSB Regulations, supra note 32 outlines the particular involvement an observer may be authorized to undertake under the supervision of an investigator. In the investigation of a pipeline occurrence, it would be common for NEB delegates to participate as observers. 
Additionally, if a person "has a direct interest in the subject-matter of the investigation and will contribute to achieving the Board's object," that person may attend as an observer at an investigation at the Board's invitation. ${ }^{263}$ Pursuant to section 24(1), “[o]n completion of any investigation, the Board shall prepare and make available to the public a report on its findings, including any safety deficiencies that it has identified and any recommendations that it considers appropriate in the interests of transportation safety." 264

There are numerous provisions set out in sections 28 to 31 of the TSB Act addressing matters of privilege and limitations on, or prohibitions against, the disclosure and use of certain records and information obtained under the TSB Act. Notably, a statement given under section 19 cannot be used "against the person who made it in any legal or other proceedings except in a prosecution for perjury or for giving contradictory evidence or a prosecution [for an offence under the TSB Act], ${ }^{265}$ which relate only to resistance or obstruction of investigators in the execution of their powers, or to giving false or misleading information or reports. ${ }^{266}$

\section{ENVIRONMENT AND Climate CHANGE CANADA AND FISHERIES AND OCEANS CANADA}

ECCC and DFO officials have inspection and investigation powers under numerous pieces of federal environmental legislation that may be triggered in the event of an oil and gas incident or emergency. The incident might constitute an environmental emergency under the CEPA or may result in harm to wildlife or the destruction of habitat protected under the Species at Risk Act. ${ }^{267}$ The incident may result in the deposit of a substance that is harmful to migratory birds protected under the Migratory Birds Convention Act, $1994,{ }^{268}$ or it may result in the release of a deleterious substance into water frequented by fish causing serious harm to fish protected under the Fisheries $A c t .{ }^{269}$ We examine the inspection and investigation powers set out in those statutes below. We note that, in our experience, it appears to be the general practice of ECCC and the DFO officials to attend with warrants even though the same may not be expressly required in all circumstances.

\section{a. Canadian Environmental Protection Act, 1999}

Enforcement officers have broad inspection powers set out in section 218(1) of the CEPA, which provides that an enforcement officer may, at any reasonable time, enter and inspect any place if there are reasonable grounds to believe, among other things, that there is: (i) a substance or product containing a substance to which the Act applies in the place; (ii) the place is a source in respect of which regulations under sections 167 (air pollution) or 177 (water pollution) apply, or a place in which regulations under section 200 apply (substances that, if released into the environment may constitute an environmental emergency or danger to the environment or human life or health); or (iii) "any books, records, electronic data or

TSB Act, ibid, s 23(2)(d).

Ibid, s 24(1).

Ibid, s $30(7)$.

Ibid, s 35.

SC 2002, c 29 [SARA].

SC 1994, c 22 [MBCA].

Supra note 217. 
other documents relevant to the administration of [the Act] can be found in the place."270 Entry into a "private dwelling-place or any part of a place that is designed to be used and is being used as a permanent or temporary private dwelling-place" must, however, only be with the "consent of the occupant" or "under the authority of a warrant."271

When carrying out an inspection, the enforcement officer's specific powers include: examining any substance, product, or any other thing relevant that is found in the place; opening and examining receptacles or packages; “" examining] books, records, electronic data or other documents that the enforcement officer believes on reasonable grounds contain any information relevant to the administration of [the CEPA] and [making] copies of them or [taking] extracts from them"; taking samples; and conducting any tests or taking any measurements. ${ }^{272}$ An enforcement officer may also use any computer system at the place to examine any data, reproduce any record, or take a printout, and may use copying equipment to make copies. ${ }^{273}$

Under section 219(1) of the CEPA, the Minister may, by registered letter or demand served personally, require any person to produce any books, records, electronic data, or other documents that may contain any information relevant to the administration of the CEPA or provide any samples of anything relevant to the administration of the CEPA. Section 219(2) provides that any person who is required to produce anything under subsection (1) must do so "despite any other law to the contrary." 274 As noted above, however, in light of University of Calgary, this general statutory language should not be understood as abrogating the entitlement to make proper claims of legal privilege over certain documents.

Where the purpose of entry is to search and seize anything that will afford evidence in respect of the commission of an offence under the Act, a warrant for the search and seizure must be obtained prior to entry. ${ }^{275}$ An enforcement officer may, however, exercise the powers of search and seizure without a warrant if the conditions for obtaining the warrant exist but there are exigent circumstances such that it would not be practical to obtain the warrant. ${ }^{276}$ Further provisions addressing the seizure and detention of things found during the course of an inspection or a search are set out in section 223 of the CEPA.

The owner or person in charge of a place entered by enforcement officers must provide all reasonable assistance to enable enforcement officers to carry out their duties and must provide any information with respect to the administration of the CEPA and the regulations that the enforcement officers may reasonably require. ${ }^{277}$ Further, it is prohibited to provide

CEPA, supra note 75, s 218(1). As noted above, no regulations have yet been passed under sections 167 or 177 of CEPA.

Ibid, s 218(2).

Ibid, s 218(10).

Ibid, s 218(13).

Ibid, s 219(2).

Ibid, s 220(1). This provision appears to expressly recognize the predominant purpose test set out in Jarvis, supra note 215, which we discuss further in Part IV, below.

CEPA, ibid, s 220(4). Exigent circumstances are stated to include "circumstances in which the delay necessary to obtain a warrant ... would result in danger to human life or the environment or the loss or destruction of evidence" (ibid, s 220(5)).

Ibid, s 227. 
false or misleading statements or otherwise obstruct or hinder the enforcement officers exercising their duties under the CEPA. ${ }^{278}$

\section{b. Species at Risk Act}

Section 86(1) of the SARA provides that "[f] or the purpose of ensuring compliance with [the Act], the regulations or an emergency order, an enforcement officer may ... at any reasonable time enter and inspect any place in which the enforcement officer believes, on reasonable grounds, there is any thing ... or any document relating to [a provision in the Act $].{ }^{, 279}$ In the course of any such inspection, the enforcement officer may

(a) open or cause to be opened any container that the enforcement officer believes, on reasonable grounds, contains that thing or document;

(b) inspect the thing and take samples free of charge;

(c) require any person to produce [a] document for inspection or copying, in whole or in part; and

(d) seize any thing by means of or in relation to which the enforcement officer believes, on reasonable grounds, the provision has been contravened or that the enforcement officer believes, on reasonable grounds, will provide evidence of a contravention. ${ }^{280}$

The enforcement officer may not, however, enter a dwelling-place except with the consent of the occupant or under the authority of a warrant. ${ }^{281}$

In carrying out the inspection, an enforcement officer can

(a) use or cause to be used any computer system at the place to examine any data contained in or available to the computer system;

(b) reproduce any record or cause it to be reproduced from the data in the form of a printout or other intelligible output;

(c) take a printout or other output for examination or copying; and

(d) use or cause to be used any copying equipment at the place to make copies of the record. ${ }^{282}$

The "owner or the person in charge of a place entered by an enforcement officer" must provide all reasonable assistance to enable the enforcement officer to carry out his or her duties and must provide any information with respect to the administration of the SARA and the regulations "that the enforcement officer may reasonably require."283 Further, it is prohibited to provide false or misleading statements or otherwise obstruct or hinder the enforcement officer. ${ }^{284}$ 


\section{c. Migratory Birds Convention Act, 1994}

Inspections can be carried out under section 7(1) of the $M B C A$ for the purpose of verifying compliance with the Act. ${ }^{285}$ At any reasonable time, a game officer may "enter and inspect any place ... in which they believe, on reasonable grounds, there is any thing to which [the $M B C A]$ or the regulations apply or any document, record, or data relating to the administration of [the $M B C A$ ] or the regulations [thereunder]." 286 The game officer may open any container that he or she believes contains any thing or document; inspect any thing or take samples; require any person to produce a document for inspection or copying, in whole or in part; use any computer system at the place to examine any data; reproduce any record from the data; take printouts for inspection or copying; use any copying equipment at the place to make copies; and seize anything which he or she believes, on reasonable grounds, will provide evidence of a contravention. ${ }^{287}$ The game officer may not, however, enter a dwelling-place except with the consent of the occupant or under the authority of a warrant. ${ }^{288}$

Section 8 provides that, for the purpose of ensuring compliance with the $M B C A$ and the regulations thereunder, a game officer may exercise the powers of search and seizure provided in section 487 of the Criminal Code ${ }^{289}$ without a search warrant if the conditions for obtaining a warrant exist but, by reason of exigent circumstances, it would not be feasible to obtain one.

\section{d. Fisheries Act}

In the part of the Fisheries Act that addresses fisheries protection and pollution prevention, section 38(1) provides that the Minister may designate persons as inspectors or analysts for the purposes of the administration and enforcement of the Act. ${ }^{290}$ Such inspectors

may, for a purpose related to verifying compliance with [the Fisheries Act], enter any place or premises ... other than a private dwelling-place or any part of any place or premises ... used as a permanent or temporary private dwelling-place — in which the inspector believes on reasonable grounds that

(a) there is anything that is detrimental to fish habitat; or

(b) there has been carried on, is being carried on or is likely to be carried on any work, undertaking or activity resulting or likely to result in

(i) serious harm to fish that are part of a commercial, recreational, or Aboriginal fishery, or to fish that support such a fishery, [or]

(ii) the deposit of a substance in water frequented by fish or in any place under any conditions where the substance or any other substance that results from the deposit of the substance may enter any such water. ${ }^{291}$

Supra note 268, s 7(1).

Ibid.

Ibid, ss 7(1)(a)-(d).

Ibid, ss 7(3)-(4).

RSC 1985, c C-46.

Supra note 217, s 38(1).

Ibid, s 38(3). 
The inspector may "examine any substance or product in the place or premises, take samples of it and conduct tests and measurements." 292

Notably, the Fisheries Act contemplates duties to notify an inspector or a fishery officer without delay of, among other things, an occurrence (or of a serious and imminent danger of an occurrence) "that results in serious harm to fish that are part of a commercial, recreational or Aboriginal fishery," 293 or if "there occurs a deposit of a deleterious substance in water frequented by fish that is not authorized under [the Act] ... and detriment to fish ... may reasonably be expected to result from the occurrence." ${ }^{294}$ Additionally, the owner

of any place or premises entered by an inspector ... and every person found there shall give the inspector all reasonable assistance to enable the inspector to carry out their duties and functions ... and shall provide the inspector with any information with respect to verifying compliance with [the Fisheries Act] that the inspector requires. $^{295}$

Where the inspector's purpose for entry is to search for evidence of an offence in circumstances where the inspector has reasonable grounds to believe that an offence has been committed, a search warrant must be obtained. ${ }^{296}$ The inspector may nevertheless exercise the powers of entry and search without a warrant "if the conditions for obtaining the warrant exist but by reason of exigent circumstances it would not be practical to obtain the warrant." 297

\section{TRANSPORT CANADA - TRANSPORTATION OF DANGEROUS GOODS DIRECTORATE}

a.

\section{Transportation of Dangerous Goods Act, 1992}

Inspectors designated by the Minister of Transport under section 10 of the TDGA are given a certificate, which is to be shown upon entering any place or inspecting any thing, that designates the matters in respect of which they may conduct inspections including the purposes, classes of dangerous goods, means of containment, means of transport, and places. ${ }^{298}$ Their powers are set out in section 15 of the TDGA, which provides that they may, at any reasonable time, stop any means of transport for which the inspector is designated and enter and inspect any place, or any such means of transport, if the inspector believes on reasonable grounds that in or on the place or means of transport there are

(a) dangerous goods being offered for transport, handled or transported;

(b) means of containment being manufactured, repaired or tested on which a compliance mark is displayed or will be affixed;

Ibid, s 38(3.1).

Ibid, s 38(4).

Ibid, s $38(5)$.

Ibid, s 38(10).

Ibid, s 39(1). This provision appears to expressly recognize the predominant purpose test set out in Jarvis, supra note 215, which we discuss further in Part IV, below.

Fisheries Act, ibid, s 39(4). Again, exigent circumstances are stated to include "circumstances in which the delay necessary to obtain a warrant would result in danger to human life or safety or the loss or destruction of evidence" (ibid, s 39(5)).

Supra note 99, s 10. 
(c) standardized means of containment;

(d) books, shipping records, [ERAPs], security plans or other documents that contain any information relevant to [the TDGA]; or

(e) computer systems, data processing systems or any other electronic devices or media that contain information relevant to the purposes of [the TDGA], or that have such information available to them. ${ }^{299}$

In the course of carrying out an inspection, inspectors may:

(a) open and inspect, or request the opening and inspection of, any means of containment for which the inspector is designated, including any closures, valves, safety release devices or other appurtenances that are essential to the use of the means of containment to contain dangerous goods, if the inspector believes on reasonable grounds that it is being used to handle or transport dangerous goods or to contain dangerous goods offered for transport;

(b) open and inspect, or request the opening and inspection of, any means of containment [being manufactured, repaired or tested on which a compliance mark is displayed or will be affixed or any standardized means of containment], including any closures, valves, safety release devices or other appurtenances that are essential to the use of the means of containment to contain dangerous goods;

(c) for the purpose of analysis, take, or request the taking of, a reasonable quantity of anything the inspector believes on reasonable grounds to be dangerous goods;

(d) examine, or request the examining of, information [in books, shipping records, ERAPs, security plans, other documents, computer systems, data processing systems, or any other electronic devices] that the inspector believes on reasonable grounds is relevant to the purposes of [the TDGA] and make, or request the making of, copies of any of it; and

(e) ask questions of any person for the purposes of [the TDGA]. ${ }^{300}$

\section{Furthermore, an inspector}

may remove to an appropriate place any dangerous goods, the means of containment being used to handle or transport them or a standardized means of containment, or direct a person to do so, and may detain the thing removed until satisfied that the activity will be done in compliance with [the TDGA], if the inspector believes on reasonable grounds that any of the following activities is being carried out in a way that does not comply with [the TDGA]:

(a) importing, offering for transport, handling or transporting dangerous goods; or

(b) selling, offering for sale, delivering, distributing, importing or using a standardized means of containment. $^{301}$

An inspector "may also take any other measures necessary to remedy the non-compliance or direct a person to take the necessary measures." ${ }^{\prime 302}$ In the course of conducting an inspection, "an inspector may not enter a dwelling-place except with the consent of the occupant or under the authority of a warrant" 303 and, in executing the warrant, must not "use

$\begin{array}{ll}299 & \text { Ibid, s 15(1). } \\ 300 & \text { Ibid, s 15(2). } \\ 301 & \text { Ibid, s 17(1). } \\ 302 & \text { Ibid, s 17(2). } \\ 303 & \text { Ibid, s 16(1). }\end{array}$


force unless the inspector is accompanied by a peace officer and the use of force has been specifically authorized in the warrant." 304

It is an offence to "fail to comply with any reasonable request of an inspector ... knowingly make any false or misleading statement" to the inspector, remove or interfere with anything detained, or "otherwise obstruct or hinder the inspector." ${ }^{305}$

In addition to the foregoing power to inspect for purposes of monitoring compliance with the TDGA and TDG Regulations, the Minister of Transport may authorize inquiries to be conducted in certain circumstances. In particular, pursuant to section 21 of the TDGA, an inquiry may be conducted "[i]f a release of dangerous goods from a means of containment being used to handle or transport dangerous goods has resulted in death or injury to any person or damage to any property or the environment." ${ }^{\text {"306 }}$ The Minister "may direct a public inquiry to be made, subject to the [TSB Act], and may authorize any person or persons that the Minister considers qualified to conduct the inquiry." ${ }^{307}$ The person who conducts the inquiry must "ensure that, as far as practicable, the procedures and practices for the inquiry are compatible with any investigation procedures and practices followed by any appropriate provincial authorities." ${ }^{308}$ Additionally, a report "together with the evidence and other material that was before the inquiry" must be submitted to the Minister as soon as possible after the inquiry and must be published by the Minister within 30 days thereafter. ${ }^{309}$

Finally, the Minister of Transport also has the power to compel the disclosure of certain information. In particular, the Minister may make a written request of "any manufacturer, producer, distributor or importer of any product, substance or organism [seeking] the disclosure of information relating to its formula, composition or chemical ingredients ... that the Minister considers necessary for the administration or enforcement of [the TDGA]." 310 Parties receiving such a request must provide the requested information within the time and in the manner specified in the notice. ${ }^{311}$ Subject to certain exceptions, information received by Transport Canada pursuant to these provisions, as well as information obtained by inspectors exercising their powers under section 15 of the TDGA or information provided to CANUTEC when reporting a release or anticipated release under section 18 of the TDGA, is treated as privileged. ${ }^{312}$ Provisions protecting the disclosure of such privileged information are set out in sections 24(3) and (4) of the TDGA. 


\section{B. Alberta}

\section{Alberta ENERGy REgUlator}

\section{a. Responsible Energy Development Act}

The AER derives its authority under the REDA, which includes the AER's investigation and inspection powers. ${ }^{313}$ The mandate of the REDA includes (i) monitoring and enforcing "safe and efficient practices in the exploration for and the recovery, storing, processing and transporting of energy resources"; 314 (ii) monitoring "energy resource activity site conditions and the effects of energy resource activities on the environment"; ${ }^{315}$ and (iii) monitoring and enforcing "compliance with energy resource enactments and specified enactments in respect of energy resource activities". ${ }^{316}$ As we noted above, "energy resource enactments" include the OGCA, OSCA, and the Pipeline Act, among others, as well as all associated regulations and rules. ${ }^{317}$ The "specified enactments" are defined as (i) the EPEA; (ii) the Public Lands Act; $;^{318}$ (iii) the Water Act; ${ }^{319}$ (iv) Part 8 of the Mines and Minerals Act; ${ }^{320}$ and (v) all associated regulations and rules. ${ }^{321}$

Section 69(1) of the REDA provides that the AER "has all the powers and functions relating to inspections, investigations and other compliance and enforcement matters under energy resource enactments and ... under specified enactments." ${ }^{322}$ The AER provides a summary of its audit, inspection, and investigation functions, and its approach to discharging those functions, in "Manual 013: Compliance and Enforcement Program." 323 Additionally, following the NEB's lead, the AER began posting information relating to its compliance and enforcement activities publicly on its "Compliance Dashboard." 324 Specifically, the AER publishes information relating to reported incidents, the status of ongoing AER investigations, compliance and enforcement decisions, administrative penalties, AER orders, and notices of non-compliance.

REDA, supra note 165

Ibid, s 2(2)(f).

Ibid, s 2(2)(i).

Ibid, s 2(2)(j).

Other energy resources enactments include the Coal Conservation Act, RSA 2000, c C-17, the Gas Resources Preservation Act, RSA 2000, c G-4, and the Turner Valley Unit Operations Act, RSA 2000, c T-9, which are outside the scope of this article. See REDA, ibid, s 1(1)(j).

RSA 2000, c P-40.

RSA 2000, c W-3.

RSA 2000, c M-17.

REDA, supra note 165, s 1(1)(s). Notably, where the specified enactments are concerned, the AER only has jurisdiction in respect of energy resource activities. Accordingly, its inspection and investigation powers would not extend to activities that are not energy resource activities under the REDA (for example, power plants or landfills). Inspections and investigations in respect of those activities are conducted by other agencies, such as Alberta Environment and Parks under the EPEA and the Water Act. REDA, ibid, s 69(1).

323 Alberta Energy Regulator, "Manual 013: Compliance and Enforcement Program” (Calgary: AER, 2016), online: <www.aer.ca/documents/manuals/Manual013.pdf $>$.

324 Alberta Energy Regulator, "Compliance Dashboard," online: <www1.aer.ca/ComplianceDashboard/ index.html $>$. 


\section{b. Oil and Gas Conservation Act}

The AER has broad powers to examine, inquire into (in other words, investigate), hear, and determine all matters and questions arising under the OGCA. ${ }^{325}$ The AER's associated inspection powers are set out in section 96(1) of the OGCA, which provides that at any reasonable time, each person authorized by the AER:

(a) shall have access to all wells, equipment, plant and records,

(b) is entitled to enter on and inspect any well or any place at which oil or gas is refined, produced, handled, processed or treated or any place used or occupied in connection with a well or with a place at which oil or gas is refined, produced, handled, processed or treated,

(b.1) is entitled to enter on and inspect any well, or any place used or occupied in connection with a well, that is used for the storage or disposal of any substance to an underground formation,

(c) is entitled to inspect all books, documents, records, plant and equipment pertaining to any such well or place or found at the well or place, and

(d) is entitled to take samples or particulars or to carry out any tests or examinations desired. ${ }^{326}$

Licensees, contractors, and operators must permit or assist AER inspectors in the exercise of these powers. ${ }^{327}$ Indeed, it is an offence to prevent, hinder, obstruct, or fail to permit or assist an AER inspector in the exercise of these powers. ${ }^{328}$

\section{c. Oil Sands Conservation Act}

Like under the OGCA, the AER has exclusive jurisdiction to examine, inquire into (i.e. investigate), hear, and determine all matters or questions arising under the OSCA. ${ }^{329}$ It may "make any just and reasonable orders or directions that it considers to be necessary to effect the purposes of [the OSCA]," 330 which include assisting "the Government in controlling pollution in the development and production of the oil sands resources of Alberta," 331 and ensuring "the observance, in the public interest, of safe and efficient practices in the exploration for and the recovery, storing, processing and transporting of oil sands, discard, crude bitumen, derivatives of crude bitumen and oil sands products." ${ }^{332}$ Provisions substantially similar to those set out in section 96 of the OGCA are set out in section 8 of the OSCA, including in respect of inspection powers, a person's duty to assist inspectors exercising their duties under OSCA, and the creation of an offence for hindering or failing to assist inspectors exercising their duties.

OGCA, supra note $118, \mathrm{~s} 94$.

Ibid, ss 96(1)(a)-(d).

Ibid, s 96(3).

Ibid, s 96(4).

OSCA, supra note 120 , s 5.

Ibid, s 6.

Ibid, s 3(e).

Ibid, s 3 (g). 
d. The Pipeline Act

The AER's investigation powers with respect to pipelines are set out in section 4 of the Pipeline Act, which provides that the AER may inquire into and examine any matters relating to

(a) the economic, orderly and efficient development in the public interest of pipeline facilities in Alberta;

(b) the observance of safe and efficient practices in the construction, operation, discontinuation and abandonment of pipelines;

(c) the observance of safe and efficient methods in any work, operations or activities when a ground disturbance in a controlled area is being undertaken; [and]

(d) the control of pollution and conservation of the environment in the development, operation, discontinuation and abandonment of pipeline facilities. ${ }^{333}$

Provisions substantially similar to those set out in section 96 of the OGCA and section 8 of the OSCA are set out in section 5 of the Pipeline Act, including in respect of inspection powers and a person's duty to assist inspectors exercising their duties under the Pipeline Act. The creation of an offence for hindering or failing to assist inspectors exercising their duties is set out in section 52(3) of the Pipeline Act.

\section{e. Environmental Protection and Enhancement Act}

The inspection and investigation powers under Part 10 of the EPEA differ quite markedly from those set out in the energy resource enactments and, in some respects, bear closer resemblance to the powers under federal environmental protection legislation. Part 10 of the EPEA must be read in conjunction with sections 25 to 28 , which provide for the designation of, and distinction in powers granted to, inspectors and investigators. In particular, inspectors have only those powers set out in section 26 of the EPEA, which are a subset of the broader powers granted to investigators. ${ }^{334}$ Notably, upon entering any place, inspectors and investigators must, "on request, produce [their] identification card and identify and explain the nature of the powers or duties [they intend] to carry out." 335

Section 198(1) of the EPEA governs inspection and investigation powers and provides that for the purpose of the administration of the Act (and subject to section 199, which provides that an inspector or investigator may not enter a private dwelling place except with the consent of the occupant or under the authority of an order or search warrant) an inspector or investigator may, without a search warrant, among other things, enter and inspect any place to determine the "extent ... to which a substance may cause, is causing or has caused an adverse effect," 336 or "enter and inspect any place in or from which the investigator reasonably believes a substance is being, has been or may be released into the

Pipeline Act, supra note 122, s 4.

EPEA, supra note $146, \mathrm{~s} 26$ provides that inspectors have those powers and duties set out in ss 198(1)(a)-(e), 198(f)(i)-(ii), 198(5), 201-203, 208.

Ibid, s 28.

Ibid, s 198(1)(a)(i). 
environment." ${ }^{, 337}$ In the course of exercising these powers, section 198(5) provides that the inspector or investigator may do any or all of the following:

(a) require that any thing be operated, used or set in motion under conditions specified by the investigator;

(b) use any machine, structure, material or equipment in the place the investigator is inspecting in order to carry out the inspection;

(c) take samples of any substance or thing;

(d) conduct tests or take measurements;

(e) make copies of or take extracts from any documents ...;

(f) use any computer system at any place to examine any data contained in or available to the computer system;

(g) record or copy any information by any method;

(h) reproduce any record from data in the form of a printout or other intelligible output;

(i) take a printout or other output for examination or copying;

(j) use any copying equipment to make copies;

(k) take any photographs or audio-visual records;

(l) make reasonable inquiries of any person, orally or in writing. ${ }^{338}$

Notably, where an inspector or investigator exercises the power under section 198(5)(1) to question individuals, the investigator "may exclude from the questioning any person except counsel for the individual being questioned." 339 As we outline in further detail in Part IV, this is different from the approach taken by AOHS investigators, who routinely exclude legal counsel when questioning individuals in the aftermath of an accident.

The EPEA further provides that an investigator may, without a court order or search warrant, seize any thing that is produced to the investigator, or that is in plain view, during an inspection under section 198. However, the investigator must have reasonable grounds to believe that there has been an offence committed under the Act and that the thing will afford evidence as to the commission of the offence. ${ }^{340}$ An inspector does not have these powers. Additionally, while these provisions appear to authorize warrantless searches and seizures in certain circumstances, there are also provisions contemplating circumstances in which court orders, search warrants, and even "tele-warrants" may be obtained. ${ }^{341}$

Finally, "the owner of and every person found in any place in respect of which an inspector or investigator is exercising powers" under the EPEA must give "all reasonable

Ibid, s 198(1)(c).

Ibid, s 198(5).

Ibid, s 198(7).

Ibid, s 204(1). Where a thing is seized without warrant, however, it must still be dealt with in the same way as if it were seized under authority of a "search warrant" (ibid, s 205), which is defined under section 194(e) of the EPEA as meaning a search warrant issued by reason of the operation of section 3 of the Provincial Offences Procedure Act, RSA 2000, c P-34 (this section, in turn, provides that except to the extent that they are inconsistent with the Act and subject to the regulations, all provisions of the Criminal Code, including provisions in Part XV respecting search warrants that are applicable in any manner to summary convictions and related proceedings, apply in respect of every matter to which the Provincial Offences Procedure Act applies. The Provincial Offences Procedure Act applies broadly, subject to any express provision in another Act, to every case in which a person commits or is suspected of having committed an offence under an enactment for which that person may be liable to imprisonment, fine, penalty, or other punishment). 
assistance to enable the inspector or investigator" to carry out those powers and provide "all information relative to the exercising of those powers ... that the inspector or investigator may reasonably require." 342

\section{f. Water Act}

The inspection and investigation powers are set out in Divisions 1 and 2, respectively, of Part 10 of the Water Act and are similar to those set out in the EPEA. ${ }^{343}$ The various powers and duties of inspectors versus investigators are, however, more clearly differentiated in the Water Act. Sections 119, 120, and 129 of the Water Act, in particular, are substantially similar to the inspection and investigation powers set out in section 198 of the EPEA.

Unlike the EPEA, section 122(1) of the Water Act provides that

[a]n inspector may, without a search warrant, seize anything that is produced to the inspector or that is in plain view during an inspection ... if the inspector has reasonable grounds to believe

(a) that an offence has been committed under [the] Act, [and]

(b) that the thing will provide evidence of the commission of the offence. ${ }^{344}$

The Water Act additionally requires that in order to rely on this seizure power, the inspector must also have reasonable grounds to believe "that the delay in waiting for an investigator to obtain a search warrant could result in the loss or destruction of evidence." ${ }^{345}$ Moreover, section 122(3) of the Water Act makes it clear that "[a]n inspector may not exercise any [power of seizure without a warrant] if, prior to entering the place, the inspector has reasonable grounds to believe that an offence was committed under [the] Act and the purpose of the entry was to secure evidence as to the commission of the offence." ${ }^{\prime 346}$

Like under the EPEA, "the owner and every person found in any place in respect of which an inspector ... is exercising powers under [the Water Act]" must provide "all reasonable assistance to enable the inspector" or investigator to carry out those powers and provide "all information relative to the exercising of those powers ... that the inspector" or investigator "may reasonably require." "347 Similarly, it is an offence under the Water Act to interfere with an inspector or investigator exercising powers under the $A c t,{ }^{348}$ to provide "false or misleading information, data, records, reports or documents as required under [the] Act"; ${ }^{349}$ or to fail "to provide information, data, records, reports or documents as required under [the] Act." 350

Ibid, s 122(3) [emphasis added]. This provision appears to recognize the predominant purpose test outlined in Jarvis, supra note 215, which we discuss further in Part IV, below.

Water Act, ibid, s 123. See also Water Act, ibid, s 131, regarding investigations.

Ibid, s 142(1)(r).

Ibid, s $142(2)(\mathrm{a})$.

Ibid, s 142(2)(b). 
2. Alberta Labour - Occupational Health and Safety

\section{a. Occupational Health and Safety Act}

Health and safety officers appointed under section 5 of the OHSA in the exercise of their general inspection powers set out in section 8(1) may

(a) at any reasonable hour enter into or on any work site and inspect that work site;

(b) $\ldots$ require the production of any records, books, plans or other documents that relate to the health or safety of workers and may examine them, make copies of them or remove them temporarily for the purpose of making copies;

(c) inspect, seize or take samples of any material, product, tool, appliance or equipment being produced, used or found in or on the work site that is being inspected;

(d) make tests and take photographs or recordings in respect of any work site;

(e) interview and obtain statements from persons at the work site. ${ }^{351}$

In the event "a person refuses to allow an officer to exercise any powers under [section 8(1)] or interferes ... with the officer in the exercise of those powers, a Director of Inspection may apply to the Court of Queen's Bench for an order restraining that person from preventing or interfering in any manner with the officer in the exercise of those powers." 352

In the event of an accident, section 19(1) provides officers with broad powers to investigate the cause of the accident and the circumstances related to the accident. ${ }^{353}$ Every "person present at an accident when it occurred or who has information relating to the accident shall, on the request of an officer, provide ... any information respecting the accident that the officer requests." ${ }^{354}$ Moreover, the officer "may, for the purposes of determining the cause of the accident, seize or take samples of any substance, material, product, tool, appliance or equipment that was present at, involved in or related to the accident." ${ }^{355}$ As in the case of statements given during inspections under section 8, any statements given to an officer in the course of a section 19 investigation "are not admissible in evidence for any purpose in a trial, public inquiry under the Fatality Inquiries Act or other proceeding" except to prove non-compliance with section 19 , or to prove the offence under section 41(3) of having provided a false statement under the Act. ${ }^{356}$

OHSA, supra note 67, ss 8(1)(a)-(e). Where statements are given under section 8(1)(e), they are "not admissible in evidence for any purpose in a trial, public inquiry under the Fatality Inquiries Act or other proceeding except to prove" non-compliance with this section or to prove the offence under section 41(3) of having provided a false statement (OHSA, ibid, s 8(5)).

352 Ibid, s 8(4).

353 Ibid, s 19(1).

354 Ibid, s 19(2).

355 Ibid, s 19(3).

356 Ibid, s 19(5). 


\section{AlbERTA TRANSPORTATION — DANGEROUS GOODS}

\section{a. Dangerous Goods Transportation and Handling Act}

In addition to having adopted the federal TDG Regulations for operation in Alberta, Alberta Transportation and Transport Canada have entered into an agreement respecting the administration of the DGTHA and TDGA ${ }^{357}$ The Administration Agreement is in place to ensure that the legislation is being applied in an equal and uniform way to minimize economic impacts on industry and ensure the orderly and safe movement of dangerous goods through the transportation system. Notably, article 3 of the Administration Agreement addresses inspection and enforcement matters, including the assessment and monitoring of ERAPs, and outlines which jurisdiction will be primarily responsible for undertaking such work under particular circumstances. ${ }^{358}$ The consequence of the Administration Agreement is that, but for inspection and enforcement activity relating to the handling, offering for transport, transporting, or importing of dangerous good by federally regulated rail carrier, aircraft, or ship, most inspection and enforcement activity carried out in Alberta is undertaken by ATDG.

Inspectors are designated pursuant to section 6 of the DGTHA and their inspection powers, which are substantially similar to those set out in the federal legislation, are set out in section 7. As is the case under the federal legislation, warrants are required to enter into a dwelling place and force cannot be used unless the inspector is accompanied by a peace officer and the use of force is authorized under the warrant. ${ }^{359}$ Inspectors have the same powers to detain dangerous goods and the means to contain dangerous goods under particular circumstances, ${ }^{360}$ and the same prohibitions against obstructing or hindering inspectors found in the federal legislation are also set out in the DGTHA. ${ }^{361}$ Inspectors also have the same powers to take certain measures to prevent an imminent release of dangerous goods from a means of containment being used to handle or transport the dangerous goods, or to reduce any danger to public safety resulting from a release. ${ }^{362}$

Finally, like under the federal legislation, Alberta's Minister of Transportation may direct that a public inquiry be conducted where "a release of dangerous goods from a means of containment being used to handle or transport dangerous goods has resulted in death of or injury to any person, danger to health or public safety or damage to any property or to the environment." 363

Transport Canada, "Canada-Alberta Agreement Respecting the Administration of the Transportation of Dangerous Goods Act, 1992" (28 October 2009), online: <www.tc.gc.ca/eng/tdg/clear-agreementsalberta-385.htm $>$ [Administration Agreement].

Ibid.

DGTHA, supra note $175, \mathrm{~s} 8$.

Ibid, s 9 .

Ibid, $\mathrm{s} 11$.

Ibid, s 12.

Ibid, s 16. 


\section{INCIDENT RESPONSE AND INVESTIGATION MANAGEMENT}

In this part, we assume that the dreaded call has been received; there has been a major incident, the ERP has been activated, and the emergency response team has been called upon to assume the roles that have been practiced through tabletop exercises and full drills. Perhaps there has been an explosion, or a major pipeline release has migrated into a significant water body. Maybe a roof has collapsed during the construction of a large oil sands facility, or there has been a well blowout. The event may even be wholly unrelated to operational issues, such as the need to evacuate camps and facilities due to wildfires or flooding. Employees may have sustained serious injuries, or you may even be dealing with one or more fatalities. Below we provide guidance in respect of some of the regulatory and legal issues a company may encounter and that will require the assistance of in-house or external legal counsel over two time horizons: (a) the immediate response to the incident (that is, the first 24 hours); and (b) the investigations, both internal and external, that may follow in the days, weeks, and months ahead.

\section{A. IMMEDIATE INCIDENT RESPONSE}

\section{PRE-INCIDENT PLANNING}

A company's response to any incident can only be as effective and efficient as were its preparations and training for just such an incident. A major incident can seriously affect the operations of a company. For example, an incident that requires the shutdown of all or part of an oil and gas company's operations will require the company's marketing department to immediately commence notifications that there will be changes to their receipts and deliveries, perhaps invoking force majeure provisions under the associated agreements, for an as-then unknown period of time. There may be human resources, personnel, and morale issues. Similarly, where an incident requires a partial or full-site evacuation, employee and contractor notifications will be required, decisions will need to be made about how to treat displaced employees, contracts will need to be reviewed to determine what obligations exist in relation to emergency situations, and extensive logistical coordination and support arrangements will be required.

Consequently, planning and preparing adequately for the variety of incidents that may occur is critical to being able to effectively respond and to reduce the risk and severity of loss. Actions taken in the first minutes following an emergency are critical. Knowing how to respond and who to contact can save lives and reduce the nature and scope of damage and liability should a significant incident occur. In Part II of this article, we outlined some of the legislative obligations to prepare ERPs for various types of potential incidents, and associated obligations to provide training to employees and to conduct regular exercises of the ERPs.

It should be recalled that the guidance provided by various regulators, including by the AER in Directive 071 , for example, generally includes only minimum requirements. ${ }^{364}$ It is 
incumbent upon those preparing ERPs, and upon counsel advising companies in respect of ERPs, to ensure that such plans are tailored to the particular risks and hazards associated with the particular operations of the company. The types of hazards to be addressed by the ERP must include both work-related hazards, and hazards that may be introduced by natural disasters, man-made events, and technological failures. A company's ERP should identify potential disasters or emergency situations that a company may face, bearing in mind the nature of its operations, including such matters as the location of facilities (for example, remote locations and issues associated with access to first responders, or proximity to residents and the need for specialized evacuation procedures). When working with external experts in developing corporate-level and site-specific ERPs, care must be taken to ensure that the unique needs and risks presented by the specific operations of the company are communicated in detail.

ERPs should contemplate reasonably likely worst-case scenarios, and plans for dealing with them must be developed, communicated, and tested. Where tests identify issues or potential weaknesses in the plan, consideration must be given to whether revisions to the plan are necessary. The specific requirements for the plans required under various statutes applicable to the oil and gas industry are set out in Part II, above.

\section{INITIAL POST-INCIDENT RESPONSE}

\section{a. Emergency Operations Centre Activation}

When a significant emergency event occurs, a company's emergency notification system is triggered and, where applicable, the company's ERP and emergency operations centre (EOC) are activated. The EOC is an operations centre established in a suitable location to manage the more significant aspects of an emergency. The location of the EOC, and whether there may be more than one EOC location, will depend upon the nature of the emergency. For example, a significant remote site-based incident may have an EOC located at the company's site, as well as at an office location. In addition, dependent upon the emergency level and the regulator(s) with jurisdiction over the incident, there may be a field centre incident command post or other regional EOC. In circumstances where there has been a full evacuation of a site (for example, the Fort McMurray wildfires of 2016), the EOC may be based solely at an office location. Notably, following the Fort McMurray wildfires of 2016, the Alberta Government (through the Alberta Emergency Management Agency) ${ }^{365}$ developed several emergency training modules relating to the operations of EOCs as part of an incident command system, which have been adopted by several major operators in the region as mandatory training for employees.

The Alberta Emergency Management Agency (AEMA) leads the coordination, collaboration, and cooperation of all organizations involved in the prevention, preparedness, and response to disasters and emergencies. These organizations include government, industry, municipalities, and first responders. AEMA works together with the AER under the "Energy Resources Industry Emergency Support Plan" (Alberta Energy Regulator \& Alberta Emergency Management Agency, "Energy Resources Industry Emergency Support Plan" (2015), online: <www.aema.alberta.ca/documents/ERIESP_FINAL2_(2). $\mathrm{pdf}>$ ) to coordinate the Government of Alberta's response to energy industry incidents. See Alberta Energy Regulator, "Responding to an Energy Incident: Fact Sheet" (April 2016), online: <www.aer.ca/ documents/enerfaqs/IncidentResponse FS.pdf>. 
In the immediate aftermath of an event, personnel are working to secure the scene, with the priority being the safety of personnel and the public, including residents or other stakeholders in the area, followed by the protection of the environment, and then the protection of assets. ${ }^{366}$ Once any injured personnel have been evacuated and the scene has been secured, efforts should be made to prevent contamination of the site and any evidence, and to ensure hazards are controlled. Particular consideration should be paid to nearby activities and how the environment could destroy or degrade evidence. Access to the area should be limited to only those people who need to be there. Attention should also be paid to whether there are any regulatory restrictions in relation to disrupting the scene of the incident. For example, section 18(6) of the OHSA provides that:

Except as otherwise directed by a Director of Inspection, an occupational health and safety officer or a peace officer, a person shall not disturb the scene of an accident reported under subsection (1) except insofar as is necessary in

(a) attending to persons injured or killed,

(b) preventing further injuries, and

(c) protecting property that is endangered as a result of the accident. ${ }^{367}$

Consequently, when an incident occurs that is reportable under section 18 of the OHSA, particular attention must be paid to ensuring the scene is not disturbed until after the report is made and AOHS advises that the scene can be disturbed.

Where a company has an in-house legal department, it should be considered whether legal counsel should be physically present at the EOC in order to provide timely legal advice (external counsel may be called upon for the same purpose where no in-house legal department exists). Part of emergency preparedness planning should, however, include identifying appropriate legal counsel (whether in-house or external) to be "on call" in the event that an incident occurs. For the reasons outlined in further detail below, largely related to the protection of legal privilege, such counsel should be engaged at the earliest opportunity following a significant incident. Where there is no in-house legal department and no legal representative present at the EOC, the decision of whether to contact external counsel once an ERP has been activated should be an initial action item of a member of the company's EOC team (for example, the EOC Director or a designate). When in-house legal counsel physically attends at the EOC, he or she may also engage external counsel as required.

\section{b. Regulatory Notifications}

After the scene has been secured, any injured personnel have been treated or transported to the hospital for further care, and all reasonable measures are being taken to confine and address the environmental impacts associated with the incident, the EOC team's attention should turn to ensuring that all applicable regulatory notifications are completed. and potential evacuation of members of the public who work or reside within the applicable EPZ, as discussed in greater detail in Part II of this article, above. 
Requirements and timing for regulatory notifications will depend on the nature and scale of the incident, but are generally required to be made as soon as practicable after becoming aware of the incident. ${ }^{368}$ Generally speaking, regulatory notifications require that sufficient factual information has been gathered, but should not be delayed if certain information has not yet been obtained, as reports can always be supplemented as more information becomes available. Additionally, many operating and environmental approvals require the immediate notification of the regulator in the event of a breach of any of the terms and conditions of the approval. These requirements will often be triggered in the event of a serious incident.

Depending upon the nature of the incident, for any activity on provincial Crown lands in Alberta, regulatory notifications can include the RCMP, the AER, AOHS, ECCC, DFO, local authorities (for example, urban centres, municipal districts, First Nations, and Alberta Health Services), the Workers' Compensation Board, the Alberta Electric System Operator, Alberta Emergency Management Agency, Alberta Boilers Safety Association, ATDG, CANUTEC, ambulance services, the local fire department, and the industrial fire service. In accordance with Directive 071, information regarding whose responsibility it will be to contact the applicable regulators in the event of an emergency along with the procedures for contacting and maintaining communication with key licensee personnel, government agencies, support services, key stakeholders, members of the public, and the media, must all be included in a company's ERP. ${ }^{369}$

While the various regulators accept that some time is required in the wake of a serious incident to initiate appropriate response measures and secure the scene, reporting is expected to be relatively immediate and one of the most prevalent non-compliances that we came across in our research was the failure to report in a timely manner in accordance with legislative requirements. As to just how immediate reporting is expected to be, it is worth noting that in 2014, Plains Midstream Canada ULC (Plains) was charged with, and pled guilty to, failing to report a release from its Rangeland pipeline system into the Red Deer River as required under section 110 of the EPEA in circumstances where (i) a producer group in the area, of which Plains was a member, had reported the incident to the ERCB within an hour and a half of the first Supervisory Control and Data Acquisition (SCADA) alarm detecting an issue; and (ii) where Plains was in communication with the ERCB for purposes of classifying the emergency level and release volumes and in communication with Alberta Environment and Sustainable Resource Development within about four hours of the initial SCADA alarm. This is shown in the incident timeline set out in Alberta Energy Regulator, "AER Investigation Report: Plains Midstream Canada ULC NPS 12 Rangeland South: Pipeline Failure and Release into the Red Deer River” (Calgary: AER, 2014) at 1-2, online: <www.aer.ca/documents/reports/IR_20140304-PlainsRangeland.pdf >. This example can be contrasted against other more common cases where the AER has levied administrative penalties in circumstances where the licensee does not uncover a continuing release until well after it has commenced. In such cases, it is not the failure to report when the release becomes known that constitutes the contravention, but, rather, the failure to report a release when the licensee ought to have known of the release based on the reasonable steps that ought to be taken to identify failures. See e.g. Alberta Energy Regulator, "Administrative Penalty Director's Decision: Murphy Oil Company Ltd." (Calgary: AER, 2017), where Murphy Oil reported a pipeline failure and release of 1429 cubic metres of diluent upon its discovery 45 days after the release commenced. A daily administrative penalty amount was imposed for each of the 45 days on which the contravention occurred or continued prior to its discovery and reporting by Murphy Oil. See also Alberta Energy Regulator, "Investigation Summary Report 2013004: Apache Canada Ltd." (Calgary: AER, 2015), where the AER found a contravention of section 110 of the EPEA in circumstances where Apache reported a pipeline failure and the release of 15,363 cubic metres of produced water when it was discovered 27 days after the release commenced. The AER found that Apache ought to have known of the pipeline break. If the pipeline pressure anomaly and meter log discrepancies would have been acted upon, it is likely that Apache would have discovered the pipeline break sooner and reported it as required by section 110(1) of the EPEA.

Directive 071, supra note 125 at 2.1. See for example the Energy Resources Conservation Board (ERCB now AER) investigation report in respect of the failure of Plains' Rainbow Pipeline, where its ERP was found to be deficient in a number of respects including the lack of an appropriate communications plan: Energy Resources Conservation Board, "Plains Midstream Canada ULC, NPS 20 Rainbow Pipeline Failure, License No. 5592, Line No.1, April 28, 2011" (Calgary: ERCB, 2013) at 17 [ERCB, "Plains Midstream"]. 
c. Initiating an Internal Investigation and Protecting Legal Privilege

Where a significant incident occurs and has resulted, or is likely to result, in legal proceedings against the company (or may require ongoing legal advice), legal counsel should initiate a legally privileged internal investigation in order to obtain necessary information upon which to provide legal advice relating to the event, as well as in contemplation of the anticipated legal proceedings. The following discussion is limited to investigations in respect of which legal privilege is intended to be claimed.

If it has been determined that there is a real risk of a potential legal proceeding, and an investigation has been undertaken in contemplation of such proceeding, legal counsel should consider taking appropriate steps to ensure this factual basis for a claim of privilege can be clearly demonstrated or documented. This is particularly important because such internal investigations in contemplation of a legal proceeding and for the purposes of providing legal advice may sometimes overlap with statutorily mandated investigations into an incident. It is always prudent to take special care to protect privilege over documents and other records created as part of such an investigation where there may be one or more ancillary purposes.

When initiating the internal investigation, appropriate investigation team members must be identified with reference to such factors as subject matter expertise, objectivity (in other words, some distance from the incident and underlying asset), and investigation experience (more experience is required where the root cause analysis will be particularly complex). At the outset of an investigation, it is advisable to create a comprehensive investigation plan to ensure that the investigation proceeds in a structured and thorough manner. The investigation plan should contemplate witness interviews, photographs, video, and sketches of the scene, and evidence collection, gathering, storage, and retention. The investigation plan should also document action items and associated timelines, and track progress of the investigation team. Caution should be taken to ensure that all drafts of certain documentation created by the investigation team are reviewed by legal counsel prior to finalization or wider dissemination.

Generally speaking, all relevant and material documents and other records relating to the issues in any legal proceedings will have to be disclosed to opposing parties. ${ }^{370}$ However, documents, information, and communications over which privilege is claimed are exempted from disclosure in legal proceedings.

Two types of legal privilege are potentially relevant to an internal investigation conducted in the aftermath of a significant incident: (i) solicitor-client privilege; and (ii) litigation privilege. Solicitor-client privilege prevents the disclosure of information communicated between the client and legal counsel for the purpose of obtaining and receiving legal advice. Litigation privilege protects any documents or communications created for the dominant purpose of preparing for an upcoming or anticipated legal proceeding (which includes 
regulatory proceedings ${ }^{371}$ ). These two types of privilege will typically overlap in the context of an investigation of a significant incident.

The Supreme Court of Canada summarized the distinction between solicitor-client privilege and litigation privilege in Blank v. Canada (Minister of Justice) (272 $^{37}$ as follows:

R.J. Sharpe (now Sharpe J.A.) has explained particularly well the differences between litigation privilege and solicitor-client privilege:

It is crucially important to distinguish litigation privilege from solicitor-client privilege. There are, I suggest, at least three important differences between the two. First, solicitor-client privilege applies only to confidential communications between the client and his solicitor. Litigation privilege, on the other hand, applies to communications of a non-confidential nature between the solicitor and third parties and even includes material of a non-communicative nature. Secondly, solicitor-client privilege exists any time a client seeks legal advice from his solicitor whether or not litigation is involved. Litigation privilege, on the other hand, applies only in the context of litigation itself. Thirdly, and most important, the rationale for solicitorclient privilege is very different from that which underlies litigation privilege. This difference merits close attention. The interest which underlies the protection accorded communications between a client and a solicitor from disclosure is the interest of all citizens to have full and ready access to legal advice. If an individual cannot confide in a solicitor knowing that what is said will not be revealed, it will be difficult, if not impossible, for that individual to obtain proper candid legal advice.

Litigation privilege, on the other hand, is geared directly to the process of litigation. Its purpose is not explained adequately by the protection afforded lawyer-client communications deemed necessary to allow clients to obtain legal advice, the interest protected by solicitor-client privilege. Its purpose is more particularly related to the needs of the adversarial trial process. Litigation privilege is based upon the need for a protected area to facilitate investigation and preparation of a case for trial by the adversarial advocate. In other words, litigation privilege aims to facilitate a process (namely, the adversary process), while solicitor-client privilege aims to protect a relationship (namely, the confidential relationship between a lawyer and a client).

R.J. Sharpe, "Claiming Privilege in the Discovery Process", in Law in Transition: Evidence, [1984] Special Lect. L.S.U.C. 163, at pp. 164-65. ${ }^{373}$

Additionally, such privileges can only be abrogated by statute where the intent is expressed through clear, explicit, and unequivocal language. ${ }^{374}$

Precautions should be taken to ensure that a claim of privilege relating to an internal investigation can be substantiated, as regulators may seek to argue that the dominant purpose of the investigation was not in contemplation of litigation or for the purposes of seeking legal advice. The regulator may argue such investigation was undertaken in the ordinary course 
of business or, as discussed below, pursuant to a regulatory requirement. It is important that when a significant incident occurs that has resulted, or is likely to result, in legal proceedings against a company, legal counsel be engaged as soon as possible.

There are a number of steps that can be taken to ensure that: (a) the factual basis for the claim of privilege can be substantiated and (b) a waiver of such privilege does not occur. Though taking the following steps may not necessarily result in the ability to successfully claim privilege, they may be considered best practices:

1. Manage the dissemination of documents and information for which privilege may be asserted to avoid inadvertent disclosure by:

a. Ensuring, to the extent reasonably practical, that communications regarding the incident and associated investigation flow through legal counsel and, where not practical, that those individuals disseminating documents and information are made aware that they should be mindful that such documents and information being disseminated should be consistent with the purpose for which the investigation was originated.

b. Ensuring care is taken to determine the recipients (including those copied) of email and other communication. The number of persons that may be considered as "need to know" in relation to an event will vary depending on the circumstances and should be determined in consultation with legal counsel. Wider dissemination of communications (including to employees, contractors, or consultants not directly involved with the incident or investigation) increases the risk that persons will waive privilege by improper disclosure of the information. In particular, care should be taken with email (for instance, avoiding careless copying or forwarding to third parties that could potentially jeopardize its status as privileged).

c. Eliminating or carefully managing communications with third parties about an incident or investigation.

d. Ensuring all external communications associated with an incident are reviewed by legal counsel prior to release or distribution.

e. Establishing a single, secure and confidential electronic and physical location where all documents and information associated with the incident and associated investigation will be stored.

2. Have legal counsel initiate the associated investigation and, as soon as practicable, confirm as much in writing. Although the involvement of legal counsel will not guarantee the success of a claim of privilege, it is an important factor that can assist in demonstrating that the dominant purpose of such investigation is in contemplation of a likely legal proceeding and that the incident and associated investigation is one for which the organization will require legal advice. In this regard: 
a. Make it clear in any documentation establishing, explaining, or otherwise created as part of the investigation that it was prepared or created for legal counsel's use in providing legal advice and for use in upcoming or anticipated legal proceedings. Label any such documents as "prepared at the request of counsel in anticipation of litigation and for the purpose of providing legal advice" or "privileged and confidential". This will also serve as a reminder to others to take care how the documents are later used or disseminated.

b. Have legal counsel retain any external experts that are engaged for the investigation. Expert reports should be sent by the expert directly to legal counsel for further distribution as appropriate.

c. Ensure that legal counsel has discussed the concept of legal privilege and the protocols required to maintain privilege with any investigators and experts engaged in respect of the investigation, as well as and those with access to the investigation materials.

d. Ensure that witnesses and others interviewed as part of the investigation have discussed with legal counsel that the purpose of the interview is to prepare legal advice for the company and in anticipation of legal proceedings.

e. Ensure that any discussions regarding hypotheses, assumptions, analyses, and conclusions relating to the incident are conducted in the presence of legal counsel.

f. Ensure that all communications are vetted and approved by legal counsel prior to dissemination outside of the investigation team or "zone of privilege."

3. Ensure that legal counsel is involved in all aspects of the investigation.

A number of the foregoing steps to protect privilege were recently addressed by the Alberta Court of Queen's Bench in Alberta v. Suncor Energy Inc. ${ }^{375}$ where the Court considered Suncor's claims of solicitor-client and litigation privilege over a number of documents that AOHS had requested production of in the aftermath of a workplace fatality. Notably, the Court quotes at length from the affidavit evidence of Suncor's in-house counsel filed in support of the claims to privilege, which provides helpful context regarding the steps to be taken at the outset of an internal investigation to protect that privilege in the face of demands from the regulator. We provide a summary of Suncor below, including the subsequent ruling of the Alberta Court of Appeal, which reversed the decision in part and was released very shortly before the publication of this article.

As outlined in Part II, above, in the wake of an accident or serious injury in the workplace, an employer is statutorily mandated under the OHSA to carry out an investigation into the 
circumstances surrounding the accident and to prepare a report outlining those circumstances and any corrective action taken to prevent a recurrence, which must be made available to AOHS. ${ }^{376}$ AOHS will routinely issue a demand under section 18 of the OHSA for such a report when a reportable incident occurs. In Suncor, the company undertook an internal investigation into the circumstances surrounding the employee's death as a result of electrocution. On the same day the accident took place, as a result of Suncor's assessment of the information available to it, legal counsel requested an investigation be conducted in contemplation of a likely legal proceeding and in order for Suncor's legal counsel to provide legal advice to Suncor. The internal investigation team was constituted the same day, and the team was provided with the direction to conduct the investigation on a privileged and confidential basis. This advice was based on Suncor's legal counsel having reached the conclusion that "litigation was a real and distinct possibility" and that "a thorough internal investigation ... would be needed to provide Suncor with the necessary information to provide proper and fulsome legal advice concerning the Accident and in anticipation of, or in contemplation of, [likely litigation being] brought against Suncor." 377

AOHS also commenced an investigation into the accident, and served Suncor with several demands under section 19 of the OHSA, one of which demanded that Suncor produce

a. Copies of all notes, records, photos/videos, documents, TapRoot or other safety root cause determination process that were taken or collected by the Suncor Investigators;

b. Copies of all photographs/videos taken respecting the Incident; and

c. Copies of all witness statements and interviews taken with respect to the Incident [as part of Suncor's internal investigation]. ${ }^{378}$

AOHS officers also "sought to interview individual members of Suncor's internal investigation team." 379 Suncor declined to provide copies of witness statements and interviews collected as part of its internal investigation, claiming the same to be privileged. While Suncor produced the requested list of "all persons interviewed with respect to the Accident, as well as the names and contact information of its internal investigation team," Suncor maintained its claim of privilege over its internal investigation and expressly asserted that the information provided should not be taken as a waiver of its claim to privilege. ${ }^{380}$

AOHS rejected Suncor's claim to privilege, taking the position that, as the conduct of an investigation is mandatory under section 18(3) of the OHSA, Suncor had collected the information for the dominant purpose of meeting its statutory obligation, not for the dominant purpose of preparing for litigation. ${ }^{381}$ AOHS also asserted that a "privilege free era" existed, which spanned from the time the incident occurred until the time that Suncor's section 18 report was submitted. ${ }^{382}$ Suncor maintained its position, and AOHS levied a $\$ 5,000$ administrative penalty against Suncor for failing to produce the requested

OHSA, supra note 67, s $18(3)$.

Suncor ABQB, supra note 375 at para 6 .

Ibid at para 7 .

Ibid.

Ibid at para 12

Ibid at para 13 .

Ibid at para 52. 
information. ${ }^{383}$ Suncor appealed the issuance of the administrative penalty to the Occupational Health and Safety Council, which granted the appeal overturning the penalty. ${ }^{384}$

The issue of whether Suncor's claim of privilege over its internal investigation was valid came before the Court of Queen's Bench by way of an originating application for declaratory relief. $^{385}$ The Court considered the "interface" between Suncor's assertion of litigation privilege over information and records collected during its internal investigation and its statutory obligation to conduct an investigation. In particular, the Court considered "whether litigation privilege can exist to cover documents created in the process of a single investigation carried out in the context of a statutory requirement that an investigation must be conducted by the same entity claiming litigation privilege." ${ }^{386}$

The Court concluded that the fact that a single investigation has a dual purpose (that is, statutory requirement and litigation) does not in and of itself "extinguish nor abrogate a claimant's right to legal privilege, where the claimant has been able to establish that the dominant purpose for conducting the investigation was in contemplation of litigation." 387 Although Suncor had a statutory obligation to conduct the investigation,

that obligation does not foreclose or preclude Suncor's entitlement to litigation privilege for all purposes, particularly if the evidence demonstrates that Suncor had taken deliberate steps to cloak documents and information collected in the process of the investigation with the garb of privilege in anticipation or contemplation of litigation. ${ }^{388}$

To find otherwise would “prejudice Suncor's right to defend itself against any potential civil actions, criminal prosecutions or regulatory claims" "389 and "defeat the policy justification and purpose of the law in relation to litigation privilege." 390

The Court noted that its conclusion was consistent with the British Columbia Court of Appeal's decision in Raj v. Khosravi, ${ }^{391}$ where it was held that "[a] claim of privilege will succeed when a party can establish that a document produced for ... multiple purposes, one of them being litigation, was produced for the dominant purpose of litigation." 392

Based on the uncontroverted affidavit evidence of Suncor's in-house counsel, the Court accepted that the dominant purpose for Suncor's conduct of the internal investigation was in contemplation of litigation. The Court accepted that based on the

Suncor ABCA, supra note 375 at para 10.

Suncor Energy Inc v Her Majesty the Queen in Right of Alberta, Occupational Health and Safety Council, Appeal from Administrative Penalty (21 November 2016), online: OHSC $<$ https://work.alberta. ca/documents/ohsc-decisions/ohsc-suncor-vs-ohs.pdf $>$.

Suncor ABQB, supra note 375 at para 13.

Ibid at para 31.

Ibid at para 44. Note that the Court relied on Thomson v Berkshire Investment Group Inc, 2007 BCSC 50,2007 BCSC 50 (CanLII), another helpful case addressing privilege in the context of statutorily mandated internal investigations.

Suncor ABQB, ibid at para 45 [emphasis in original].

Ibid at para 46.

Ibid.

2015 BCCA 49, 368 BCAC 62.

Suncor ABQB, supra note 375 at para 47, citing Raj v Khosravi, ibid at para 17. 
seriousness of the fatal Accident, the potential for various penalties and sanctions under the [OHSA], the RCMP investigation, and the [AOHS] Officers' investigation - it was reasonable for Suncor to have anticipated or contemplated that there was a very good chance [of] litigation ... including the likelihood of regulatory prosecution by the [AOHS], laying of Criminal Code charges, or civil litigation. ${ }^{393}$

The Court noted that section 18(3) of the OHSA limited the employer's post-investigation duties to preparing a report and ensuring a copy of the report was readily available for inspection, and found that "these legislative provisions neither contemplated nor expressly authorized access to the individual author(s) of the statutory report for an account of the process adopted in writing the report, excepting where as an individual s/he was 'present at an accident when it occurred or [has] information relating to the accident.",394

The Court's views were reinforced by the fact that AOHS had the broad statutory power under section 19 of the OHSA to conduct an independent investigation into the accident, and did commence such an investigation on the same day as Suncor, which included interviewing 15 witnesses regarding the accident. ${ }^{395}$ The Court considered that the "limited use immunity" provisions in sections 18(5) and 19(5) of OHSA were also indicative of the legislature's intent to extend some form of privilege to the investigation conducted by Suncor and the statutory report prepared through that process. ${ }^{396}$ Denying Suncor's claim of litigation privilege over information obtained through the same investigation that underpinned the section 18 statutory report would

fly in the face of the legislature's intention to make that statutory report inadmissible 'as evidence for any purpose in a trial arising out of the serious injury or accident, an investigation or public inquiry under the Fatality Inquiries Act or any other action as defined in the Alberta Evidence Act except in a prosecution for perjury or for the giving of contradictory evidence. ${ }^{, 397}$

The assessment of which particular documents or records were created during Suncor's internal privileged investigation was directed to the Court of Queen's Bench Case Management Counsel to act as a referee. ${ }^{398}$ The role of the referee was to establish the process for the identification and assessment of privileged records and make recommendations to the Court as to which of the records, documents, and information regarding the incident were covered by solicitor-client or litigation privilege. ${ }^{399}$

While the decision of the Court of Queen's Bench in Suncor was rendered prior to the Supreme Court of Canada's decisions in University of Calgary and Lizotte, it was entirely consistent with the strong protection afforded to claims of solicitor-client privilege and litigation privilege in the face of production requests from regulators in those cases.

The Alberta Court of Appeal released its decision in respect of AOHS's appeal on 30 June 2017. Most significantly, it applied the Supreme Court's decisions in University of Calgary

Suncor ABQB, ibid at para 65.

Ibid at para 70, citing OHSA, supra note 67, s 19(2).

Suncor, ABQB, ibid.

Ibid at para 71 .

Ibid, citing OHSA, supra note 67, s 18(5).

Suncor ABQB, ibid at para 92.

Ibid at paras 92,95 . 
and Lizotte in confirming that sections 18 and 19 of the OHSA do not preclude claims of litigation privilege. ${ }^{400}$ The Alberta Court of Appeal, however, took issue with the chambers judge's formulation of legal privilege:

The approach taken by the chambers judge is shown in the [Suncor] Decision, para 68 :

\begin{abstract}
Based on the uncontroverted affidavit evidence of Mr. Chell, I find that, in the circumstances of the Accident and the course of actions taken by Suncor's legal counsel - beginning on the same day the Accident occurred - the dominant purpose for Suncor's conduct of the subject investigation into the Accident was in contemplation of litigation. This finding invariably and logically leads to the collateral finding that, within the context of Suncor's internal investigation that was carried out in anticipation of litigation, the information and documents created and/or collected during the internal investigation with the dominant purpose that they would assist in the contemplated litigation, are integrally covered by litigation privilege. (emphasis in original)
\end{abstract}

In our view, this formulation of legal privilege by the chambers judge is overbroad and in error. Even if the dominant purpose of the internal investigation as a whole was in contemplation of litigation, this does not mean that every document "created and/or collected" during the investigation assumes the mantle of that overarching dominant purpose so as to be clothed with legal privilege. ${ }^{401}$

The Court also concluded that the chambers judge erred in finding the lists that Suncor provided to AOHS describing its privileged documents were sufficient to allow an assessment of the privilege claims. ${ }^{402}$ The Court specifically noted that Suncor's lists asserted both solicitor-client and litigation privilege over nearly all of its documents, an approach that could result in a litigation tactic that ought to be discouraged. ${ }^{403}$ In reliance upon Canadian Natural Resources Ltd. v. ShawCor Ltd., ${ }^{404}$ the Court of Appeal noted that the inquiry into privilege must consider the purpose for which each document (or bundle of like documents) was created, as opposed to the purpose for which it was collected. ${ }^{405}$ In terms of necessary specificity in describing documents, the Court held that although documents may frequently be subject to both solicitor-client and litigation privilege, the party claiming one or both types of privilege must independently distinguish which privilege applies and why:

Parties must describe the documents in a way that indicates the basis for their claim: ShawCor at para 9. The grounds for claiming solicitor-client privilege and litigation privilege are distinct. A description that supports one class of privilege does not necessarily support the other.

To support a claim of solicitor-client privilege, Suncor must at least describe the documents in a manner that indicates communications between a client and a legal advisor related to seeking or receiving legal advice.

Suncor ABCA, supra note 375 at para 42.

Ibid at paras 27-28. The Court provided some examples of documents that would be caught by the overly broad formulation, but would not be the subject of proper claims of privilege (ibid at para 32). In particular, the Court seemed concerned with the inclusion of documents that were not merely "collected" during the investigation, but were created prior to the incident and therefore could not have been completed in contemplation of litigation.

Ibid at para 49 .

Ibid at para 45.

2014 ABCA 289, 376 DLR (4th) 581.

Suncor ABCA, supra note 375 at paras 29, 35. 
To support a claim of litigation privilege, Suncor must describe documents with enough particularity to indicate whether the dominant purpose for their creation was in contemplation of litigation. ${ }^{406}$

In short, while the Court of Appeal has confirmed that that sections 18 and 19 of the OHSA do not preclude privilege claims (that is, there is no "privilege free era"), such claims must be adequately described and cannot be supported by general claims to both solicitorclient and litigation privilege. The Court of Appeal ultimately referred the matter back to the Court of Queen's Bench, directing that the inquiry of the referee, and ultimately the chambers judge, must focus on the dominant purpose for creating each document. ${ }^{407}$ Until this process has been completed, it is unclear how claims of legal privilege in the context of workplace incidents will be resolved.

Other cases that provide helpful analysis of issues surrounding claims of legal privilege over documents produced in the course of internal investigations include College of Physicians of B.C. v. British Columbia (Information and Privacy Commissioner) ${ }^{408}$ and R. v. Bruce Power Inc. ${ }^{409}$ In College, the British Columbia Court of Appeal held that the fact that an investigation is statutorily mandated is "irrelevant to the functional analysis of the lawyer's role" in assessing claims of privilege. ${ }^{410}$

In Bruce, the Ontario Court of Appeal restored a stay of proceedings in circumstances where an inspector under Ontario's OHS Act and Crown counsel had obtained a copy of a privileged internal investigation report prepared at the instruction of counsel in the aftermath of a workplace accident in which a worker sustained serious injuries at Bruce Power's nuclear power plant. The report was obtained from a union representative on the internal investigation team created by Bruce Power who had previously undertaken to destroy any copies of the report. ${ }^{411}$ Crown counsel intended to tender the privileged report, which included self-incriminating statements given by one of the charged individuals, in evidence at the trial. ${ }^{412}$ In restoring the stay of proceedings, the Ontario Court of Appeal accepted that the Justice of the Peace had not erred in finding (i) that the rights of the two charged individuals to a fair trial entrenched in sections 7 and 11 of the Charter had been breached by reason of the prosecutor's conduct in respect of the privileged report; ${ }^{413}$ and (ii) Bruce Power's right to a fair trial pursuant to section 11 of the Charter had been breached. ${ }^{414}$

Ibid at paras 46-48 [emphasis in original].

Ibid at para 43.

2002 BCCA 665, [2003] 2 WWR 279 [College].

2009 ONCA 573, 98 OR (3d) 272 [Bruce].

College, supra note 408 at para 39.

Bruce, supra note 409 at paras 10, 14

Ibid at paras 17, 29 .

The prosecution had prepared its case, including the calling of certain witnesses, in reliance upon the privileged investigation report. The Justice of the Peace concluded that the report contained information that could be used to the disadvantage and prejudice of the defendants (ibid at paras 31-34). Interestingly, in Bruce, the OHS Inspector was aware of the existence of the privileged report during the course of his investigation, was aware that Bruce Power claimed privilege over the report, and took no steps during the course of his investigation to seek production of the report (ibid at para 11). Ibid at paras 28,66 . 
d. Communications, Media Relations, and Responding to Inquiries

When a significant incident occurs, companies will also be dealing with numerous inquiries, including from media, shareholders, and potentially affected communities. The regulators will be looking to ensure that the company is adequately responding to such inquiries, particularly where the persons asking may be directly impacted by the incident. As such, it is important to respond to such inquiries promptly, but it is equally prudent to have legal counsel review any press releases, key messages, media statements, and responses to specific inquiries in order to provide appropriate legal advice in connection with such communications.

Notably, a communications plan addressing, among other things, contacting and maintaining communications with the public and the media is one of the specific corporatelevel ERP requirements under Directive 071.415 The AER expects licensees to provide proactive communications updates to the public and the media. Indeed, the failure to provide transparent and timely information about the incident and subsequent response efforts may be considered non-compliance events that may lead to enforcement actions. ${ }^{416}$

\section{B. MANAGING REgUlatory InSPECTIONS AND INVESTIGATIONS IN THE AFTERMATH OF AN INCIDENT}

When an incident occurs, companies should identify a (non-legal) point of contact that is best suited, based on the nature of the event, to be the company's primary contact with regulators (the Representative). The Representative should work closely with legal counsel in relation to communications and interactions with regulators. Consideration should be given to whether, in the circumstances, the Representative should also be a member of the investigation team. Depending upon the nature of the event, there could be multiple regulators responding to the incident, each of which has differing powers under its enabling legislation as we discussed in Part III, above. For example, in the event of an accident resulting in both injuries to personnel and the shutting-in of facilities falling under provincial jurisdiction, both the AER and AOHS would likely conduct investigations. Where a single point of regulatory contact for the company is identified, this can create efficiencies and can assist with consistency of information flow. However, if this is impractical or will not work for a given company or a given incident, at a minimum, the identified points of contact should be in regular contact with one another and legal counsel.

Among other enforcement actions, in the wake of the Rainbow Pipeline failure, Plains was directed by the ERCB to engage a third party to conduct a communications audit, the results of which were to be reported to the ERCB along with Plains' action plan to implement the recommendations for improvements. The communications audit was to focus on the company's ability to manage communications during a crisis or incident, including: (i) "crisis and incident response communications plans (including research, analysis, and evaluation and reporting)"; (ii) "individual roles and responsibilities"; (iii) "media relations policies and procedures and resources"; and (iv) "executive responsibility to communicate effectively with all affected stakeholders" (ERCB, "Plains Midstream," supra note 369 at 19$)$. 


\section{Regulator's AtTENDANCE AT THE Site}

In attending a site in response to a specific incident, it is common for the government or regulatory official (the Official) to identify himself or herself and the particular legislative powers he or she is attending under. However, where the Official has not clearly identified as much, an important first step for the Representative is to request identification and determine: (i) the agency the Official represents; (ii) the legislative authority for the attendance; (iii) the purpose of the visit (for example, inspection or investigation); and (iv) if the official is conducting an investigation, whether it is the company, a particular individual, or both that are the subject of the investigation. The Representative should also request that the Official immediately notify the company if the purpose of the visit changes.

The foregoing matters are significant because, as explored in Part III, above, there are differences in the scope of inspection and investigatory powers of various regulators as provided in their various governing statutes. There are also differing protections afforded to parties subjected to regulatory inspections and investigations under the various statutes. While the various regulators' powers are broad, they are not absolute and it is entirely appropriate to ensure that the legislative authority for the attendance is understood, and the proper bounds of the visit are established at the time of entry. This should, however, be done in a professional manner without improperly hindering or obstructing the Official.

Understanding the purpose of the visit and the Official's target can be integral in ensuring that appropriate rights are asserted and protected. In the case law addressing when the Charter protections against self-incrimination and warrantless searches and demands of production will be engaged in the context of the enforcement of regulatory laws, a line has been drawn between (i) inspections, with the predominant purpose of ensuring compliance with the law; and (ii) investigations, with the predominant purpose of determining penal liability (that is, the gathering of evidence in support of prosecution). Under this "predominant purpose" test, full Charter protections are only engaged in the latter context $\mathrm{t}^{417}$ and, even then, some Charter protections are only afforded to individuals and not the corporation itself. ${ }^{418}$ It can be difficult to distinguish between an inspection and an

Jarvis, supra note 215; Ling, supra note 215. See also The Honourable Todd L Archibald, Kenneth E Jull \& Kent W Roach, Regulatory and Corporate Liability: From Due Diligence to Risk Management (Toronto: Thomson Reuters, 2016) (loose-leaf release no 40), vol 1, ch 11; James Sprague, "Good Cop/Bad Cop: Charter Rights Against Self-Incrimination and Unreasonable Search and Seizure in the Context of Investigations in Support of a Regulatory Scheme" (2003) 16 Can J Admin L \& Prac 161; David Stratas, "CCrossing the Rubicon': The Supreme Court and Regulatory Investigations" (2003) 6 Criminal Reports (6th) 74. For criticism in respect of the predominant purpose test see Christopher Sherrin, "Distinguishing Charter Rights in Criminal and Regulatory Investigations: What's the Purpose of Analyzing Purpose?" (2010) 48:1 Alta L Rev 93.

While some Charter protections extend to corporations (for example, the section 8 right to be secure against unreasonable search or seizure and section 11(d) fair trial rights), others do not. The Supreme Court of Canada has held, for example, that section 7 of the Charter (the right to life, liberty and security of the person and the right not to be deprived thereof except in accordance with the principles of fundamental justice, which includes the right to silence) is confined to the protection of human beings and has no application to corporations: Thomson Newspapers, supra note 215. When charged, however, corporations can defend on the basis that the charging statute offends section 7 provided that the offence applies to both corporations and individuals (Wholesale Travel, supra note 215). Additionally, corporations cannot be arrested or detained and therefore cannot invoke sections 9 (the right not to be arbitrarily detained or imprisoned) and 10 (rights on arrest or detention including right to retain and instruct counsel without delay and to be informed of that right) of the Charter (Canadian Egg Marketing Agency $v$ Richardson, [1998] 3 SCR 157). See also R v Syncrude Canada Ltd, 2010 ABPC 123, 33 Alta LR (5th) 233, where the Alberta Provincial Court noted that a corporation does not have a right against self-incrimination under s 11(c) of the Charter (at para 30). 
investigation, particularly in the wake of a serious incident where the regulator may be relying on its inspection powers to assess compliance matters in circumstances where offences are already suspected or believed to have occurred. ${ }^{419}$ While mere suspicion that an offence has occurred will not be enough to demarcate the commencement of an investigation for penal purposes, ${ }^{420}$ the particular circumstances must be assessed in each case to determine the predominant purpose of the Official's attendance. ${ }^{421}$ It may even be the case that the predominant purpose of the attendance changes during the course of the visit or immediately after the first visit when there are multiple searches in one day. ${ }^{422}$

It is also important to understand the target of the investigation because if it is indeed an individual, that person should retain independent counsel separate from the company (or at least be advised to do so). As noted above, an individual also has greater Charter protections that would be engaged in the context of an investigation with the predominant purpose of gathering evidence to be used in support of that individual's prosecution.

During the attendance, the Representative should document all information regarding the date and time of the visit, identity of the Official(s), and any salient details in respect of the visit. Other things the Representative should do or keep in mind while an Official is on site include:

1. Cooperate and do not obstruct or mislead the Official; ${ }^{423}$ allow the Official to take photographs or recordings, perform tests, make inspections, and take samples (while advising of any safety concerns and asking the Official to take steps to eliminate or mitigate any safety risks). Offer to gather any materials requested by the Official. Duplicate any photographs, recordings, tests, samples, or documents taken by the Official so that the company has a complete record of what has been taken.

In Jarvis, the Court set out a number of factors to consider in assessing whether the regulator's predominant purpose is, in fact, conducting an inspection for purposes of monitoring compliance or an investigation for purposes of determining penal liability. Though Jarvis dealt with the context of income tax regulation, the Court provided guidance that may also be helpful in other regulatory schemes including those applicable in the oil and gas industry and including such factors as: (i) whether the authorities had reasonable grounds to lay charges at the time; (ii) the conduct of the Official during the inspection and whether it is consistent with a targeted investigation; and (iii) whether the inspector was effectively acting as an agent for the investigators (Jarvis, supra note 215 at para 94).

Jarvis, ibid at para 90. Note that if the Official has reasonable and probable grounds to believe that an offence has been committed, the predominant purpose is likely to be an investigation to determine penal liability and a warrant may be required.

${ }^{421}$ See $R$ v Canada Brick Ltd, [2005] OTC 611 (Sup Ct) [Brick] for an example under Ontario's occupational health and safety legislation, where the Court found that an inspector had exceeded his inspection powers by continuing to rely on those powers after he objectively had reasonable and probable grounds to believe the employer had contravened the Act. The inspector's continued reliance upon inspection powers for the purpose of gathering further evidence after that point was a warrantless search no longer authorized by law in breach of the employer's section 8 Charter right (at paras 158-164). See also Rv Inco Ltd (2001), 54 OR (3d) 495 (CA), where the Ontario Court of Appeal sent a matter back to trial to determine whether an inspector under Ontario's Water Resources Act, RSO 1990 , c O.40, had reasonable and probable grounds to believe that an offence had been committed prior to conducting certain inspections and interviewing employees in respect of a discharge of untreated mine effluent.

422 Brick, ibid. See also Rv Sutherland, 2010 ONSC 2240, 51 CELR (3d) 163, aff'd 2011 ONCA 239, 2011 ONCA 239 (CanLII), which considered the transition from an inspection to an investigation in the context of the Fisheries Act, supra note 217.

${ }_{423}$ As noted in Part III, above, almost all of the regulatory statutes expressly mandate cooperation during inspections and establish offences for any person who hinders, obstructs, or misleads the Official. This duty to cooperate assumes, however, that the Official is acting within the scope of his or her authority. 
2. Endeavour to provide, if possible under the circumstances, applicable orientation and safety training and appropriate personal protective equipment if the Official does not have his or her own.

3. To the extent not restricted by the Official, accompany the Official at all times; however, depending upon the Official and the nature of the search, employee movement may be restricted and the Representative may not be permitted to accompany the Official.

4. Where possible, seek confirmation in writing from an Official who makes a request for information, documents, materials, or interviews of personnel.

5. If the Official is attending pursuant to a search warrant, ${ }^{424}$ a copy of the warrant should be made and provided to legal counsel as soon as possible. Particular attention should be paid to the following: (i) the authority for the search; (ii) the offence alleged; (iii) who issued the warrant; (iv) what places or things may be searched; (v) what materials or items are sought; (vi) whether any of these materials or items (that is, records) are subject to legal privilege; and (vii) the date or valid period for the warrant. If the Official's search attempts to extend beyond the scope of the warrant, the Representative should, to the extent possible, note that the search is extending outside of the search warrant and should not expressly consent to such search. If the Official persists, the Representative should not impede the Official but should keep notes regarding the nature and extent to which the search extended beyond the terms of the warrant, as this may provide grounds upon which to successfully challenge the admissibility of the evidence if prosecution is pursued.

6. To the extent possible in the circumstances, the Representative should consult with legal counsel prior to:

a. Providing any records to an Official in response to a request. Where there is a claim for privilege or a claim that a record is outside of the scope of the reason for the Official's attendance, the record should be placed in a sealed envelope which should not be opened by the Official until after the parties can agree regarding whether the record is producible or until the matter has been determined by a court. If records are provided, duplicate copies should be made for the company.

b. Permitting interviews of employees or contractors by the Official. an inspection to monitor compliance. In those circumstances, what would otherwise be a presumptively unreasonable search in breach of section 8 of the Charter is generally found to be authorized by law and reasonable. Where the regulator's attendance is for the predominant purpose of gathering evidence for a prosecution, the regulator should generally have a warrant. In the authors' experience, it is the general practice of the ECCC and the DFO to routinely attend with warrants. The AER, on the other hand, rarely obtains warrants. 
7. As soon as possible upon completion of the Official's visit, and at the request of legal counsel, prepare a report documenting the details of the visit, including all interactions and steps taken and any commitments made on behalf of the company. The report should state that it has been "prepared at the request of legal counsel," and should be provided to legal counsel and not be shared, other than as directed by legal counsel.

\section{EMPLOYEE INTERVIEWS BY A REGULATOR}

As legal counsel representing a company in the context of a regulatory investigation, it is important to remember that the advice you provide is legal advice to the company, not any particular individual within the company. Accordingly, while it is prudent for legal counsel to meet with employees that will be interviewed by an Official, it is important to consider and to remind them that you are counsel for the company and that the advice you are providing is given in that capacity. Depending on the circumstances, it may be appropriate to make it known to the employee that he or she may wish to seek independent legal advice and representation. Where an individual is under investigation personally or has reason to believe he or she may become the subject of investigation in his or her individual capacity, the individual may wish to retain his or her own counsel. In some cases, and depending upon the circumstances, the company may have a policy relating to, or may otherwise consider, payment of the individual's legal fees.

When preparing employees for an interview by an Official, keep in mind that many will have no experience with these circumstances and may be extremely nervous and reticent. Accordingly, it is important to demystify the process for them so they are not unnecessarily caught off guard by any formalities in the process. For example, employees should be advised that the interview will generally be recorded and that this is normal and is for their protection too, as reliance will not be placed on the handwritten notes of the Official but on their actual words as transcribed. Other important tips to be given to employees who will be interviewed by an Official include the following:

1. Tell the truth and do not obstruct the Official.

2. Only answer questions that are asked.

3. If the question was not understood, ask that it be repeated.

4. Keep answers short and to the point.

5. Answer only questions that are within your personal knowledge. Do not speculate, guess, or provide an opinion.

6. Do not hesitate to ask for a break at any time.

Employees should also be advised that they are entitled to request that the company's legal counsel be present for the interview. The response to such requests will typically vary depending upon the regulator. For example, such requests are typically granted by the AER 
and ECCC. The practice of AOHS, however, is to invariably refuse such requests in reliance upon the decision of the Alberta Court of Queen's Bench in Ebsworth v. Alberta (Human Resources and Employment). ${ }^{425}$

In Ebsworth, the Court considered an application by an employee that had witnessed an accident in which his co-worker was killed for a declaration that AOHS officers did not have authority to exclude counsel from being present during an interview of the employee conducted under sections 8 or 19 of the OHSA. In addition to the jurisdictional argument, the employee argued that such exclusion would be a breach of his constitutional rights under sections 7 and 10 of the Charter. The Court described the central issue as being whether the employee is entitled to have counsel present in circumstances where he is compelled to give a statement pursuant to section 19(2) of the OHSA. ${ }^{426}$

The Court canvassed a number of authorities on the jurisdiction of investigating officers, and held that they were all distinguishable since the cases dealt with the substantive jurisdiction of the investigator, not its procedural authority. ${ }^{427}$ The Court relied instead on Irvine v. Canada (Restrictive Trade Practices Commission) $)^{428}$ for the proposition that an investigative body must have control of its own procedure. ${ }^{429}$ The Court found that AOHS officers must have a similar authority, so long as the exercise of that authority does not conflict with the OHSA. Unless the legislation expressly provides that counsel for a person being questioned may not be excluded, the ability to exclude counsel remains an element or procedure to be determined by the AOHS officers. ${ }^{430}$

The Court went on to consider the alleged Charter breaches, noting the importance of the regulatory, rather than penal, context of the investigation. ${ }^{431}$ The dominant purpose of requiring the employee to provide information was not to incriminate him, but to obtain information necessary to determine the cause of the workplace accident. Furthermore, the Court noted that if there were subsequent proceedings, the employee would be protected by derivative use immunity. ${ }^{432}$ This was to be distinguished from circumstances where the purpose of the agency seeking to compel a witness to provide information is to determine penal liability, in which case section 7 Charter rights are engaged. ${ }^{433}$ The Court also noted that the nature of the proceeding may change over time from an investigatory function to an inquiry into penal liability, at which point the predominant purpose of the investigation is in

2005 ABQB 976, 396 AR 345 [Ebsworth].

As noted in Part III, above, OHSA, supra note 67, s 19(2) provides that every person present at an accident when it occurred or who has information relating to the accident shall, on the request of an officer, provide any information respecting the accident that the officer requests. The failure to comply with this section (or to make a false statement) is an offence under section 41 and is punishable by fine or imprisonment for a term not exceeding 6 months. Ebsworth, supra note 425 at paras 29-30.

[1987] 1 SCR 181

Ebsworth, supra note 425 at para 31.

Ibid at para 36.

Ibid at paras $40-41$.

Ibid at para 48. The Court noted that section 13 of the Charter provides that a witness who testifies in any proceeding has the right to not have any incriminating evidence given in that testimony used against him, except in a prosecution for perjury. The Court went on to find that section 19(5) of the OHSA (which provides that any statement given under that section is not admissible in evidence for any purpose in a trial or public inquiry under the Fatality Inquiries Act except to prove perjury) is expressly consistent with the Charter.

Ebsworth, ibid at para 51, citing Jarvis, supra note 215. 
regards to penal liability and any compelled evidence would infringe Charter rights. ${ }^{434}$ In this case, however, the Court found that the AOHS investigation was clearly regulatory and not concerned with the penal liability of the Applicant. ${ }^{435}$

With respect to the employee's section 10 Charter rights, which arise only in the case of arrest or detention, the Court found that the employee was not "detained" within the meaning of the established case law and, therefore, the employee's section 10 right to counsel was not engaged. ${ }^{436}$ As for the right to counsel that the Supreme Court of Canada has identified in situations that do not trigger section 10 , but where the right to security of the person is nevertheless engaged, ${ }^{437}$ the Court found that the employee's liberty interest was not in jeopardy and any risk of future charges arising from his statement was not an imminent one. In the absence of any real or imminent deprivation of liberty, the employee's section 7 right to counsel was not engaged. ${ }^{438}$

Having found no Charter breaches, the Court almost begrudgingly held that "[a]lthough it may be desirable and perhaps even advantageous to permit the presence of legal counsel during an interview conducted pursuant to s. 19 of the OHS Act, [AOHS] has the jurisdiction to govern its procedure and to exclude the presence of legal counsel." ${ }^{439}$ In our view, the Court was gently nudging AOHS to the conclusion that its policy of excluding counsel was a bad one and, potentially, counterproductive.

In our experience, and provided counsel understands and respects AOHS's broad investigative powers, the presence of counsel does not "disrupt, frustrate, slow down, and render an investigation unworkable" as suggested by counsel for the AOHS in Ebsworth. ${ }^{440}$ Rather, it can assist in putting nervous witnesses at ease resulting in better and more complete evidence. We note that occupational health and safety legislation in other jurisdictions expressly recognizes the right of a witness to have someone present with them during interviews. ${ }^{441}$ Alberta's EPEA goes even further in expressly prohibiting investigators from excluding counsel when an individual is being questioned. ${ }^{442}$ In the absence of a policy change on the part of AOHS, in our view, this is a matter worthy of legislative change. When faced, however, with a situation where an employee is being interviewed in the absence of counsel, the employee should be advised that if, at any time during the course of the interview, he or she is advised of the right to remain silent, that right should be exercised and the employee should contact the company's legal counsel immediately (assuming the individual does not already have his or her own counsel). Legal counsel can help determine next steps.

See e.g. Workers' Compensation Act, RSBC 1996, c 492, s 184; The Workplace Safety and Health Act, CCSM c W210, s 24(1)(k); Occupational Health and Safety Act, SNS 1996, c 7, ss 50(6)-(7). EPEA, supra note 146 , s $198(7)$.
} 


\section{REGULATOR'S INVESTIGATION REPORT}

Though not necessarily the case with routine inspections, where a formal investigation has been undertaken, the regulator will typically prepare a written report outlining the determinations they have made. The scope of the report is dependent upon the legislative provisions pursuant to which the investigation has been undertaken. For example, where the TSB investigates a pipeline occurrence, its report will only contain a technical determination of the cause and contributing factors of the incident. The report will not (and should not) address the matter of any potential statutory contraventions, which are to be determined by the NEB. By contrast, when the AER undertakes an investigation of an incident under its governing legislation, the report will include both a root cause analysis and its preliminary assessment of contraventions that it may later pursue either by way of prosecution or other enforcement actions, including administrative penalties. The AER's investigation reports may also include directions for the licensee to undertake certain work to address identified non-compliances. Given the divergence in the scope of contents of investigation reports, when faced with an investigation after an incident, it is helpful to review the particular regulator's prior investigation reports to develop an understanding of what to expect and to identify common concerns raised by the regulator that can be avoided. As we find ourselves in an era of regulatory transparency, the investigation reports of regulators can often be found online. $^{443}$

Historically, some regulators have been prepared to provide a draft of the investigation report to the investigated party prior to its public release. This practice was intended to provide the investigated party with an opportunity to review the facts relied upon by the regulator in reaching its conclusions to ensure that the relevant facts have not been misstated; and not to provide the investigated party with an opportunity to challenge the regulator's findings. Even where an opportunity to review a draft is not afforded, a detailed review of the investigation report should be undertaken immediately upon its receipt to ensure that none of the relevant facts have been misstated or omitted from the report. Where possible, any errors should be brought to the regulator's attention as soon as possible, as the regulator may be prepared to issue errata. ${ }^{44}$

For example, the AER's investigation reports can be found on the compliance dashboard (Alberta Energy Regulator, "Compliance Dashboard: Investigations," online: <www1.aer.ca/compliance dashboard/investigations.html>). Archived AER reports can also be found online (Alberta Energy Regulator, "Investigation Reports," online: $<$ www.aer.ca/data-and-publications/publications/ongoinginvestigations $>$ ). The TSB's investigation reports in respect of pipeline occurrences can be found online (Transportation Safety Board of Canada, "Pipeline Investigation Reports," online: <www.tsb.gc.ca/eng/ rapports-reports/pipeline/index.asp>). The NEB's Incident Investigation Reports, as well as other compliance reports can be found online (Canada, National Energy Board, "Compliance and Enforcement," online: <https://www.neb-one.gc.ca/sftnvrnmnt/cmplnc/index-eng.html>). Finally, AOHS also publishes its Fatality Investigation Reports online (Alberta, Occupational Health and Safety, "Fatality Investigation Reports," online: < https://work.alberta.ca/occupational-health-safety/fatalityinvestigation-reports.html $>$ ). 


\section{CONCLUSION}

The oil and gas industry is facing ever more scrutiny from the public and, in turn, from the regulators mandated to protect the public interest. Spills and other emergencies have not only become the subject of regulatory investigations, but also of the nightly news and unforgiving social media campaigns. In this environment, it is crucial that energy companies not only have robust emergency response plans, but that those plans be regularly updated and tested. Even where energy companies fully embrace a culture of safety and environmental protection, and take all reasonable steps to prevent incidents that may cause harm to their workers, the public, or the environment, accidents will still occur. A well-trained team ready to respond in an emergency, including community and media relations expertise, guards not only against risk to personnel and the public, the environment, and asset(s), but also against reputational risk.

In the wake of an incident, regulators have broad investigative powers to determine the cause of the incident, assess whether there have been any contraventions of legislation or operating permits, and determine whether and what enforcement action may be appropriate under the circumstances. We have attempted to provide guidance on how best to navigate this process, which can be complicated by the potential to have multiple regulators asserting jurisdiction over differing aspects of an incident, each regulator acting under legislation with different powers and limitations. As in the case of responding to the emergency itself, having a plan with clearly delineated roles and communications protocols is key in effectively navigating a regulatory investigation. For the reasons we have outlined, involvement of legal counsel at the earliest possible stage is crucial. 